\title{
$\mathrm{DDC}$ 주류구분법에 관한 연구
}

\section{A Study on the Main Classes of DDC}

남 태 우(Tae-Woo Nam)*

\begin{tabular}{|l|l|}
\hline & 목 차 \\
1. 서 론 & $5.1 \mathrm{DDC}$ 주류배열의 논리성 \\
2. $\mathrm{DDC}$ 이전의 주류체계 & 5.2 DDC 주류배열의 비논리성 \\
3. Amherst 대학도서관의 실정 & 6. Richardson의 주류설정에 대한 우화론 \\
4. $\mathrm{DDC}$ 초판 서문에서의 주류구분의 논리 & 7. 결 론 \\
5. $\mathrm{DDC}$ 주류배열의 논리성과 비논리성 &
\end{tabular}

\section{초 록}

이 논문은 $\mathrm{DDC}$ 의 주류설정에 대한 논리성을 규명하는데 목적이 있다. 어떤 분류법이든 군집화와 순차화가 선행된다. 주류설정은 군집화과정이다. 군집화 과정속에서 2 차적으로 순차화가 고려되는 것이다. 따라서 분류법 에서 군집화는 분류표를 구성하는데 가장 중요한 요소이다. 그렇기 때문에 주류설정에서 논리성이 강하게 요구되는데 $\mathrm{DDC}$ 에서 각 주류는 특수도서관 개념에서 출발하였기 때문에 논리성은 약하다. 그러나 역사적 사실을 통해 주류설정의 논리성을 규명하고자 하였다.

\section{ABSTRACT}

The purpose of this study is to analyze on the main classes of DDC. The DDC is a general classification system which aims to classify documents of all kinds falling in any knowledge domain. At best, the order of the main classes represents a mix of Baconian and Hegelian philosophy adulterated by the practical exigencies of organization a collection of books. Each of the main classes have been subdivided further into what are technically known as divisions. This division of knowledge into the nine main classes mirrors the educational consensus of the late nineteen-century Western academic world. The DDC thus scatters subjects by discipline, and the subjects are subordinated to discipline. The DDC has been criticised for its rigidity of division by ten at every step of its division. Division by the decimal classification has been likened to the Procrustean bed.

키워드: $\mathrm{DDC}$ 주류구분법, 문헌분류법에서의 주류, 주류설정의 원리, 문헌분류법, 듀이십진분류법, 헤겔 분류법

DDC, Main Classes, Library Classification, Hegel Classification 


\section{1. 서 론}

분류시스템에서는 2 가지 개념이 기본이 된 다. 군집화 (grouping)와 순차화(ordering)이 다. 군집화는 분류의 기본 행위로 타고난 인간 의 사고 중의 하나이다. 인간들은 본능적으로 이러한 감각으로 모든 것을 분류할 수 있다. 개 념을 군집화 하는 것뿐만 아니라, 군집화 했던 원칙을 알고 있어야 분류에는 논리적이고 철학 적인 기초가 실존하고 있음을 알 수 있다. 관련 된 용어나 개념으로 군집화하는 이 과정은 분 류체계에 주요한 부분이다. 바로 학문의 주제 를 구분하는 즉 주류결정단계이다.

두 번째 단계는 그룹 사이의 관계를 결정한 다. 이는 그룹이 배열되어질 순서를 결정한다. 정해진 정확한 순서가 있다거나 절대적인 관념 에서 배열이 다른 것보다 낫다고 말하는 것은 불가능하다. 이러한 모든 주제(전체적인 지식) 들을 정해진 것에 넣으려고 하려는 것에서 어 려움이 있다. 즉, 단일한 순서나 단일한 주제로 나타내는 것은 주제 사이에 존재하는 다양한 관계들을 고려할 수 없게 된다. 이러한 면에서 $\mathrm{CC}$ 가 합리적이라는 평가를 받는다.

순차화에 관한 일반적인 이론적 원칙은 분류 체계에 이용된다. 연대순의 순서는 당연한 것 이고, 근접은 지리학적 장소의 순서를 정하는 것에 대한 기초가 된다. 발달적 순서와 복잡성 에 기초를 둔 순서는 자연세계를 분류하는 데 에 이용될 수 있다. 그리고 의존의 개념은 생물 학의 분류에서 이용된다. 그럼에도 불구하고, 분류에서 많은 순서들은 독단적인 기초에 의해 정해진다. 그래서 문헌분류는 지식분류에 기반 함이 원칙이지만, 실제 응용상에서는 이론적이
라기보다는 실제성에 초점을 맞추는 데서 비논 리적이라고 할 수 있다.

모든 문헌분류법에서 각각의 주류를 열거하 고 있으나 이에 대한 명확한 기준이나 철학이 나 이론적 근거를 규명할 수는 없다. 시대가 발 전함에 따라 지식도 발전하고 점차 다양해지면 서 새로운 주제가 발생하게 되면서 현대 문헌 분류표의 주류수도 점차 증가해 왔다. 분류법 중에서 가장 이론적이며 체계적인 분류법이라 고 평가를 받고 있는 $\mathrm{CC}$ 마저 주류설정에 대한 어떤 기준에 의한 것인지 아무런 설명도 없다. 주류의 전개에 있어서 19 세기 말기에 창안된 $\mathrm{DDC}$ 는 주류가 10개였으나 20세기 초인 1904 년에 개발된 $\mathrm{LCC}$ 는 주류가 21개로 늘어났고, 그 후 1933 년에 편찬된 CC는 26개의 주류로 증 가했으며, 그보다 3년 후인 1936년에 편찬된 Bliss의 $\mathrm{BC}$ 는 주류가 35 개로 증가하였다.

그 후 각각의 분류표는 개정이 되면서 주류 가 LCC의 경우 하위류를 포함하여 70여개로, CC도 6판에서는 47개로 증가하고, 1987년 발 간된 7 판에서는 주류가 전판에 비해 2 배가량 증가되었다. 이와 같이 시대의 발전과 새로운 지식이 확장으로 주류의 수가 증가했다는 사실 을 입증 할 수 있다. 그렇지만 이러한 주류설정 의 원칙이나 이론 등은 전혀 연구된바가 없다. $\mathrm{DDC}$ 의 체계에 대한 논쟁은 여러 세대에 걸쳐 계속돼 왔지만 아직도 역사적인 합의를 이루지 못하고 있다. 따라서 본 연구에서는 분류표의 총체적인 구조의 근거가 되는 주류의 설정원칙 과 그 논리를 연구하고자 함이 목적으로 주 분 석대상은 $\mathrm{DDC}$ 로 한정하였다.

$\mathrm{DDC}$ 는 세계에서 가장 광범위하게 사용된 분류법이다. 1996년에 OCLC는 창안 이후 133 
년이 된 $\mathrm{DDC} 22$ 판을 출판했다. 현재 135 개국의 이상의 도서관에서는 그들 장서를 조직화하고 접근점을 제공하는데 $\mathrm{DDC}$ 를 사용하고 있으며, 60 개국 이상에서는 국가서지에 $\mathrm{DDC}$ 번호를 사 용하고 있다. DDC는 현재 30 개 이상의 언어로 번역되었다. 모든 유형의 도서관들이 $\mathrm{DDC}$ 를 기 본으로 다양한 방법(WorldCat, OCLC Online Union Catalog)으로 기본으로 하거나 공유하 고 있다. $\mathrm{DDC}$ 는 또한 다른 목적 즉 웹상의 자 원을 위한 브라우징 메커니즘에서도 사용된다.

미국 내에서만 보면 공공도서관의 $95 \%$, 전 문 도서관의 $25 \%$, 대학 도서관(대부분이 단과 대학 수준이기는 하지만)의 $25 \%$ 이상이 사용 하고 있다. 1876년에 처음 창안되었을 때에는 44 페이지의 얇은 책자 형태였지만 22판이 출판 된 지금 $\mathrm{DDC}$ 의 체계는 4,000 페이지 이상의 분 량으로 두꺼워졌다. 이러한 영향력에도 불구하 고, 그 기원에 대한 지식은 아직 미해결 과제로 남아 있다. 그 미해결 중 하나가 주류설정의 원 리도 그 중 하나이다.

\section{2. $\mathrm{DDC}$ 이전의 주류체계}

Aristoteles, Conrad Gesner, F. Bacon 그리 고 André Marie Ampere의 학문체계들은 자 발적이든 임의적이든지 차치하고 Callimachus, Ismael Bouillaud, Marlin, William T. Harris, M. Dewey 등 문헌분류에 상당한 영향력을 미 친 것으로 인식하고 있다. 그러나 그러한 영향 들은 지배적이거나 광범위하게 파급된 것은 아 니었다. 그 당시에 주어진 상항하에서는 실제 적인 편의성이 더 객관적이었다. 이것은 이론
적이라기보다는 실제성에 기반하였다는 것을 의미한다.

그래서 철학자 Gottfried W. Libniz는 장서 조직을 3 구분하고 이것은 중세대학 학부의 주 요과목인 신학, 법학, 의학에 할당하였다. 그는 문헌의 수집정책에 있어서 대중이 관심을 가지 는 문헌은 편견없이 수집하도록 하였고, 목록 은 주제목록을 채택하고 각 주제아래 서명과 저자명을 기입하여 문헌속에 포함된 주제 수만 큼 목록기입을 만들도록 하였다. 이 목록은 오 늘날의 분출목록으로서 극단적인 경우 한 문헌 에서 100 개 이상의 저록이 작성되었다. 그는 분 류법에서도 독창성을 발휘하여 Gabriel Naude 의 12 개 분야로 구성된 분류법을 10 개 분야로 구성되는 분류법을 만들어 사용하기도 하였다.

Libniz는 장서조직 중 처음 두 주제 즉 '신학 과 법학은 G. C. Brunet체계의 처음 두 주류에 나타나게 되며, 이것들은 Brunet체계와 밀접한 관련을 가졌다. 그러나 세 번째의 의학은 Konard von Gesner나 어떤 중세의 체계에까지 소급한 더 광범위한 과학과 예술에 종속되어 버렸다. 여기에는 중세 대학의 문법, 수사학 그리고 산 수, 문학, 음악, 기하, 천문학 등의 흔적이 있다. 즉 중세의 3 학 4 과에서 도출한 것이다.

F. Bacon은 지식을 역사, 시, 철학으로 구분 하였다. 그러나 그 이후의 체계에서는 문학이 라는 표제가 시를 대신하였다. Bacon의 체계가 나온지 몇 년 후 프랑스의 사서인 Naude의 체 계는 E. Edwards의 분류표(Edwards 1859)에 서 상기 주류들의 유집(類集) 현상을 가장 간 명하게 보여준다.

그러나 의학이 두 번째에 배정되고 수학이 추가되었다. 즉 I. 신학, II. 의학, III. 법률, IV. 
역사, V. 철학, VI. 수학, VII. 순수문학 순이다. Edwards의 표에서 나타난 바와 같이 Rhodius (1631), Clemens(1635), Bouillaud(1678) 그리 고 Garnier(1678)의 체계는 이러한 학문의 주 류를 그룹화하는 주된 역사적 변형물로서 전자 의 두 주류에 언어학, 논리학, 수사학, 웅변술 그리고 생리학을 추가시킨데 반하여, Bouillaud 는 이 중의 몇 개를 문학, 과학, 그리고 예술 아 래에 합하여 그의 체계를 5 개의 주류로 감소하 였다. 이것은 파리의 서적상이나 프랑스 서지 학자, 17-19세기의 사서들, 그 중에서도 특히 $\operatorname{Martin}(1740)$ 이나 Brunet(1810)의 배열의 근 간이 되었다. 간략하게 이것이 파리 혹은 프랑 스 체계(French System)로 알려져 있다.

Brunet의 『Manual du ubraire et de L'Amateur des Livres』에 분류된 부분은 구체화 되 었는데, 그 이전에 Ismael Bauillaud가 유명한 Jacguea Augest de Thou와 그의 가문의 도서 관을 위해서 고안한 체계가 있었다(Bibliotheca Thuana 1679). 이 체계는 그 후에 개정, 보완 되었는데, 1740년의 Gabriel Martin, 1768년의 Gaillaume de Bure, 반의어 익명대사전의 저 자인 1803(혹은 1806)년의 Antoine Barbier의 ${ }^{\circledR}$ Cours elementaire de bibliographie 의 C. F. Achand, 케임브리지 Queen's College
대학 사서 Thomas Horne, Brunet 등에 의해서 개정되었다. 이러한 가운데서 변화는 주류의 수 (대개 5개)와 순서에 영향을 주었는데, 마르세 이유의 사서였던 Achard에 의해서 전도되었다. 다음 〈표 1〉에서와 같이 Horne은 제 3 열의 과학, 예술을 둘로 나누고, 또 문학과 역사의 순 서를 바꾸었다. 다소간의 비슷한 변화가 많은 다른 학자들에 의해서 이루어졌다.

상기 〈표 1〉에 나타난 바처럼 신학은 프랑스 혁명의 급진주의가 문법이나 문학, 철학이나 과학을 첫 번째 주류로 내세웠던 몇몇 체계를 제외하고는 항상 첫 번째에 위치하였다. 대학 교육과 관련하여 법률은 II에 철학은 신학과 구 분하였을 경우 II가 아니라 III에 배열되는 것이 당연하였다. 문학은 철학과 분명히 다르게 구 분하였고, 역사는 위 양자와 다르게 구분하였 다. 예술과 과학의 문헌취급은 이들의 연구나 교육과정과는 또 달랐다.

독일의 서지분류는 1793 년의 Ersch에서부 터 1847년의 Schleiermacher, 그리고 1888년 의 Hartwig 분류에 이르는 기간의 몇몇 경우에 는 언어학이나 교육학이 부각되는 중요성으로 그 하나나 둘 모두가 주류 배정에 포함되기도 하였다. 이러한 6-7개의 주요 구분은 당시 견지 되었던 실제적인 목적과 관점에 부합되는 것이

〈표 1〉Brunet과 Horne의 주류체계비교

\begin{tabular}{l|l}
\hline \multicolumn{1}{c|}{ Brunet체계 } & \multicolumn{1}{c}{ Horne체계 } \\
\hline I. 신 학 & I. 신학 혹은 종교 \\
\hline II. 법 률 & II. 법 률 \\
\hline III. 과학과 예술 & III. 철 학 \\
\hline IV. 순수문학 & IV. 예술과 상업 \\
\hline V. 역 사 & V. 역 사 \\
\hline & II. 문 학 \\
\hline
\end{tabular}


었다. 그러나 아직 지식이나 학문을 조직하는 목적이 뚜렷이 부각되어 있지 않았다. Burnet 시대에도 문헌은 어떠한 원칙에 입각해서 분류 되지 않았다. 신학은 존중되었기 때문에 첫 번 째에 위치하여야 한다는 관념이었다. 그러나 역사나 문학, 철학 어느 것이 마지막에 위치하 고 또 예술이 과학에 선행여부는 차치하고 별 문제가 아니었다.

대영박물관도서관은 1836 1838년에, 영국 왕립학회는 1857년에, E. Edwards는 1859년에 그리고 L. P. Smith는 1882년에 각각 Brunet 의 분류체계를 적용하기 시작하였다. 그러나 이들을 비교해보면 상당한 부분이 변화된 것을 알 수 있다. 대영박물관도서관의 분류는 철학 을 과학과 예술 다음에 놓고, 10 주요 구분의 마 지막에 언어학을 배정한 점에서 Horne의 분류 법과 유사하다. Edwards는 6 개의 주류 $(\mathrm{A}-\mathrm{F})$ 를 생성하고 다시 이를 더 세분하였는데, 사법 을 포함하여 법률과 정치 그리고 상업을 $\mathrm{D}$ 에 종속시킨 점이다. 철학과 역사를 $\mathrm{B}$ 와 $\mathrm{C}$ 안으로 끌어들인 것이 Brunet와 크게 다르다. 이렇게 하여 $\mathrm{E}$ 의 과학과 예술에서 이것들을 분리시키 고 또 $\mathrm{F}$ 의 문학과 철학에서 이를 분리하였다.

이들 영국의 서지분류법 가운데서 마지막인 Sonnenschein의 『The Best Books(1887)』은 $\mathrm{A}$ 에서 $\mathrm{K}$ 까지 10 개의 주류로 되어있는데, 사회 를 철학 $(\mathrm{C})$ 과 지리, 역사 $(\mathrm{E}$ and $\mathrm{F}-\mathrm{G})$ 의 중간 앞부분에 위치시킴으로서 Edwards의 분류표 를 개선하였지만, 아직까지도 $\mathrm{H}$ 의 과학은 위치 가 잘못 배정되어 있다.

C. A. Cutter의 전개 분류표(EC)는 거의 동 시대에 사실상 영국의 Edwards 분류표와 똑같 은 기초위에서 개발되었지만, $\mathrm{K}$ 에 법률을 할당
하고, $\mathrm{Q}$ 에 의학을, $\mathrm{E}$ 에 전기를, $\mathrm{G}$ 에 지리·여 행을 부여하여 더욱 많은 주요구분을 갖게 되었 다. 도서관을 위한 Cutter와 그 이후의 분류표 들은 실제적, 논리적 또는 철학적 가치를 부여 하는데 목적이 있었다. 더 오래된 서지분류법일 수록 서적판매용이든 도서관용이었던 간에 차 치하고 철학적인 목적보다는 실제적이었다.

그러나 Edwards는 이론적인 것을 늘 형이상 학적이고, 환상적이며 불합리한 것이라고 폄하 시켰다. 이 점은 당시 그가 계획하고 있던 모든 체계에서 대부분 정당화되었다. 그러나 Merlin 은 1853 년 뉴욕 도서관인 대회에 제출한 글에 서 지식의 체계에 대한 도서분류의 기초의 중 요성을 강조하였다(Bliss 1939, 197). 그로부터 40년 후 Cutter는 이러한 주장을 강력하게 토 론의 장으로 끌어 들였다. Cutter의 EC와 매우 유사한 것은 1894년에 간행된 Quinn과 Brown 의 분류법이다. 그 후 1906년에 간행된 Brown 의 주제분류표(Subject Classification)는 과학 이 총류 바로 뒤에 위치하고, 역사가 언어와 문 학 뒤인 마지막에 위치함이 다르다. 이 순서는 물질과 힘(Matter and Force), 생활(Life), 정 신(Mind), 그리고 기록(Record)이라는 4가지 주요 단계를 진화론적으로 전개하여 합리화하 였다.

1870년으로 소급해서 철학자이자 교육자였던 Harris는 세인트 루이스 공립학교 도서관목록을 간행하였는데, 그는 분류표를 구체화시켜 다년 간 편집인으로 있었던 『Journal of Speculative』 에 발표하였다. 이 분류표는 철학적인 것에다 실 제적 관심을 결합하였다. 또한 과학을 가장 넓은 영역으로 하여 맨 첫 번째 표제로 삼았고, 철학 은 과학의 하위에 오고, 종교는 그 다음에 배정 
하였다. 그러나 물리, 자연과학, 수학은 Brunet, Horne, Edwards의 것과 같이 철학, 종교, 사회 과학 뒤에 위치시켰다. 이 체계는 종종 Bacon 의 3 구분법이라고 설명되는데, 다시 철학과 과 학, 예술과 문학 그리고 역사의 순으로 전도되 었다. 여기에서 18 가지 주류의 순서는 Dewey 가 채택한 9 가지 주류와 똑같고 역시 100 개의 항목을 전개시켰다.

Comte나 Ampere 그리고 Spences의 철학 적 체계가 학계에서 얼마나 영향력이 있었는지 모르지만 서지적인 면에서 Bacon이나 Burnet 는 19세기 말까지 영국, 프랑스, 이태리에서 지 배적이었고, 넓은 의미에서는 오늘날까지 그러하 다. Bacon은 이태리에서 특히 영향력이 있었다. 이태리 서적상들에 의해서 채용되었고(1871), Dewey가 그의 연구에 많은 자극을 받았다고 하는 Battezzati의 체계는 Burnet의 것을 적용 한 것이었다.

19세기 후반에, 만들어진 문헌분류법에 대해 주요하게 요구했던 것 중 하나는 같은 주제들 은 함께 놓아두도록 하고, 한 주제에서 또 다른 주제로의 전개는 논리적으로 하도록 하는 것이 었다. 이러한 요구 때문에 문헌분류는 난해한 문제로 매우 복잡하게 되었다. 무엇이 현실적 이론에 의한 논리적 분류인가라는 숙고는 난제 로 남겨진 것이다.

\section{Amherst 대학도서관의 실정}

Amherst College는 메사츄세츠주 서부에 있 던 장로교회파와 교회연합회에 소속된 열성적인 신도들에 의해 창설되었던 1815년의 Amherst
Academy를 모체로 해서 발전을 하여 1821년에 College로 개교를 하였다(Tyler 1895, 3). 1821 년 9월 18일에 Amherst College는 421명의 학 생으로 개교하였으며, 대학교과과정은 Yale대 학의 것을 모델로 하였다(Engley 1947, 18).

즉 1821년에 웹스터 사전을 처음 만든 Noah Webster(1758-1843) 등이 재능있고 신앙심 깊 은 남학생을 양성하기 위하여 선교활동의 일환으 로 설립되었다. Williams College의 재정위기를 계기로 학장과 일부 학생이 갈려나와 대학을 출 범시켰으며 이로 인하여 Williams College와 미 국 학부중심대학 교양대학(liberal arts college) 의 수위를 다투며 오랜 경쟁관계에 놓이게 되 었다.

이러한 연유로 교육내용은 지방 공공단체의 영향을 받아 대부분 종교적인 분야에 치중하였 다. 이는 학습내용과 교수방법 등의 보수주의 경향에 따라서 도서관의 장서가 구성되었음을 의미한다. 이처럼 개관 당시의 장서는 대부분 이 기증본으로 설립자나 후원자의 정신이 깃든 종교적인 장서가 지배적일 수밖에 없었다. 더 구나 대학의 교과과정이 종교적인 것과 고전적 인 것에 제한되어 있었으므로 장서가 불균형적 으로 소장될 수밖에 없었다.

Amherst 대학도서관은 대학의 개교와 함께 1821년 10월 1일에 개관하였다. 개관 당시의 도 서관의 규모는 겨우 6 피트 넓이의 방이었으며, 단 한 개의 책장에 모든 장서를 배열하고 있었다 (Tyler 1895, 28). 장서는 목사들이 기증한 신학 서와 다방면에 걸친 도서 약간을 가지고 개관하 였다(Tyler 1895, 313). The Boston Recorder

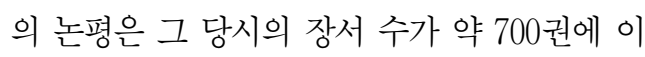
르고 있다(Tyler 1895, 29)고 밝히고 있다. 
개관시간은 일주일에 1 시간 문을 열고 대출, 반납업무를 수행했을 뿐이다(Tyler 1895, 31) 당시의 대학도서관에는 수업에 필요한 교재 몇 권 밖에 없었으며, 장서수집에 있어서도 목사 가 되기 위한 과정, 즉 종교적 예배, 부흥 등에 관한 자료에만 많은 관심을 기울였다. 도서관 발전을 위한 기금은 부족하였으나 독지가들의 기증과 가끔 대학당국에서 도서관을 지원하는 특별경비에 의존하였다. 현재 도서관에는 102 만권의 장서와 50 만여 종의 미디어 자료가 소 장되어 있다.

남북전쟁 이후 환경의 변화, 즉 교과과정의 변화와 대학에 대한 재정적인 지원의 증가로 도서구입이 활발해지고 또한 학생단체에서 자 신들의 예산으로 구입한 도서가 대학도서관에 편입되어 장서수가 급속하게 증가하였다. 이에 따라 도서관의 장서는 무질서한 혼란상태를 초 래하게 되었으며, 이러한 상태를 해결시키려는 첫 번째 시도가 1870 년대에 이르러 대학도서관 의 학생 보조원이었던 M. Dewey의 노력을 통 해 이루어진다.

미국에서 리버럴 아츠 칼리지(liberal arts college) 는 전문기술의 습득이나 준비를 위한 대 학과 달리 일반 교양과 상식, 논리 능력을 개 발 시키는데 목적을 두고 있는 대학이다. 리버 럴 아츠는 인문학, 사회과학, 자연과학, 어학 등의 '교양과목'을 가리킨다. 따라서 교양과목 에 중점을 둔 학부 중심의 4 년제 대학을 가리 킨다. 미국 일류 대학들일수록 인문자연과학교 육(liberal arts and science education)을 중요 시하고 있다.

그 이유는 어느 특정분야를 배우기보다는 일 반적이고도 포괄적인 학문을 배움으로써 바른
인성과 세상을 보는 안목을 갖는 것이 더욱 중 요하다고 생각하기 때문이다. 한 예로 의과대 학들이 과학 과목을 중심으로 지망자를 선발하 여 왔었지만 요즘에는 과학과목 외 많은 리버 럴 아츠 과목을 택할 것을 권고하고 있다. 이는 인문과학이나 사회과학을 통해 길러진 인성이 환자를 대할 때 중요하다고 간주되기 때문이다. 이러한 배경 때문에 인문학이 중시될 수밖에 없었다.

이러한 측면에서 Lois M. Chan은 "DDC에 있 어서 9 개의 주류 중에 6 개의 류가 인문과학에 속 한다는 하는 사실은 19 세기에 있어서의 학문상 황을 반영하는 것(Chan 1985, 223)" 이라고 분 석하였다. 그러나 이러한 주류배정은 19 세기의 학문의 전반적인 특성을 반영하였다기 보다는 Amherst College 교과과정의 편성과 이에 따른 도서관의 장서개발정책에 따른 소장 장서의 특성에서 기인한 것으로 볼 수 있다. Amherst College가 현재도 인문학 중심의 대학으로 각 광을 받고 있으며, 대학평가에서도 우위를 점 하고 있는 것이 그 반증이다. Dewey는 철학, 종교, 언어학, 예술, 문학 등에 대해서 사회과학, 순수과학, 응용과학 등과 대등한 위치를 부여 하였다.

Dewey의 분류법 창안이 분류목록의 작성에 서부터 발단이 시작된 것이라고 한다면, 그것 은 곧, 당시에 Amherst 대학도서관의 실정이 야말로 더욱 그 근원을 이룬 것으로 보아야 할 것이다. Dewey가 이 대학에 입학한 다음해인 1871년에 창립 50주년을 맞이했는데, 1875년 6 월 12 일 현재, 장서 수는 3 만 406권, 그 외에는 학내에 소재하는 2개의 단체(college societies: Alexandria \& Athenae)가 소장하고, 대학도 
서관으로 합병될 예정이었던 도서가 8,127권, 합 해서 3 만 8,533 권이며, 그 이전의 15 년 동안 누 년 증가 권수는 평균해서 940권이었다(Amherst College 1876, 75-77). E. C. Richardson이 DDC 초판(1876년) 간행에 관련해서, 이 분류법은 장서 4 만권 이하의 도서관을 대상으로 고안된 것이었다는 것은(Richardson 1930, 157) 이와 같은 실정을 배경으로 하고 있는 것이다.

또 이러한 도서가 서가에 놓이게 된 실정은, 서가를 크게 역사(history), 철학(philosophy), 과학(science), 신학(theology) 등 극히 교양적 인 주제 (general subject)로 배분하여 숫자화 하고, 그 아래에 개개의 서적을 단지 번호순으 로 배가하여 가는 방법이었다. 이것은 고정식 배가이며, 그 안에서도 매우 단순한 형태이다. 즉 위에 서 말한 주제별로, 서가의 순번을 더듬 어가며, 단지 들어온 순서대로 번호가 매겨지 는 것뿐, 이 이상의 세분은 이루어지지 않았다.

따라서 서가구획(tier), 책장(shelf)에 따라 기호를 따로 하는 것마저도 고려하지 않고, 소 위 '숫자배치(numerical arrangement)'의 방 법에 의한 것이다. James D. Brown에 의하면, 이 방법은 일찍이 "대다수의 영국 공공도서관 에서 행해지던 가장 일반적인 방법'이며, 역사 적으로 말하면 '숫자배가식(numeriacal location system)'에 이어지는 다음 단계에 위치하는 것 이라고 한다(Brown 1898, 13). 즉 영국에 공공 도서관 운동이 막 시작한 초기 단계에 있어서 는, 특별 교육이나 훈련을 받을 기회도 없고, 아 무런 근거할 만한 과학적 방법도 가지지 못한 상태에서 가장 안이한 방법으로 사용한 것이 전 장서를 하나의 누진번호 아래에 둔다는 이 '숫 자배치'의 방법이었다. 하지만, Brown도 기술하
고 있는 것같이, 이 방법에는 사서의 두뇌적 소모 를 극도로 경감하고, 공간의 불경제성을 제거한 다는 두 가지 관점에서 말하면, 확실히 '부정하기 어려운 이점'을 갖고 있다(Brown 1898, 15).

그래도 이 방법에 의한 경우는, 그 갖는 내용 에서는 서로 완전히 관계가 없는 형태에서 서 적은 서가상에 혼재한다. '숫자배치' 방법도 또 보편적인 몇 주제가 수용되어 그 주제로 유 또 는 강의 구성이 이루어진 점, 각 종류의 안은 입수순이라는 우연적 순서에 근거한 누진번호 이며, 여기에서도 또 종류의 내부에 있어서 각 종 주제의 도서가 혼재했던 모습을 갖는다. 1870년대에 있어 Amherst 대학도서관의 실정 은, 확실히 이 '숫자배치’에 의한 것이었지만, 그러나 이 방법을 취하기에 이르는 것도, 1855 년부터 세어 정말 수년전의 일에 지나지 않았 다고 한다. 어쩌면 그 이전에 있어서는 보다 단 순한 '숫자 배가법'에 따르고 있었을 것이다.

더욱이 또 이 대학도서관의 목록에 대해서 말 하면, 이 대학이 'college'로서 재편성을 한 1821 년부터 34년 후(1855)에는, 1 만 2천권의 장서 에 대해, 저자명에 의한 어순목록이 간행되었 는데, 그것은 개개의 도서에 대해 서가번호와 그 서가 내에 차지하는 도서번호 2 개를 부기한 것이었다. 이것을 시초로 해서 9년 후(1864)에 는 1855 년 이후의 증가분에 대해, 카드에 의한 저자목록을 추가보충하여 가는 방침이 세워졌 다. Dewey 시대에 아울러 그간 창립 50주년을 맞이한 1871 년에는, 1 만 4,300권에 대한 같은 저자목록이 보유(補遺) 로서 인쇄되었다. 결국 이 대학은, 종류로서는 인쇄책자 목록과 카드 목록, 형태로서는 저자목록을 가진다. 따라서 주제를 근거로 한 목록작성을 고려하지 않고 
1870 년에 이르렀다는 것이 가능하다. Dewey 가 이 도서관 안에서 먼저 눈여겨 본 것은, 실은 이와 같은 목록의 존재에 대한 것이었다. 그가 '기원논문'중에서 '뛰어난 주제색인을 갖고 싶 다는 우리들의 커다란 요망'으로 적고 있는 점 에 의해서도 그 일면을 엿볼 수 있다.

\section{4. $\mathrm{DDC}$ 초판 서문에서의 주류구분의 논리}

이병수는 DDC 16판의 "Melvil Dewey의 서 설(introduction)'의 역자서문에서 '서설(序說)' 이 지닌 가치와 의미를 다음과 같이 설명하고 있다. "모든 십진분류법의 원전이 되는 것은 Dewey 분류법”이며, 이 Dewey의 분류법의 구 성원리와 운용방법을 상세하게 말해 주는 것은 그 서설이다. 그러기 때문에 십진법을 알려면 $\mathrm{DC}$ 를 읽어야 하고 그것의 구성원리와 운용방 법을 알려면 그의 서설을 읽고 익히어야 한다. DC가 1876년 초판을 낸지 한 세기가 지나고 그 의 원대한 서설이 쓰여 진 지 한 제너레이션 반 이 지났건만, 그의 분류법이 지금도 환영을 받 고 모든 십진분류법 편찬의 원전이 되었듯이 그의 서설은 모든 분류법의 설명과 사용지침으 로 되어 오늘날까지 그 의의를 그대로 지니고 있다. 이러한 의미에서 $\mathrm{DC}$ 나 그의 서설은 옛 것이지만 언제나 새 것이며 나이는 먹었지만 영원히 젊음을 지닌 틀림없는 분류법의 고전 중의 고전인 것이다(이병수 1965,1 ).

서론이란 전체의 글이 무엇에 관한 글인지를 밝히고, 논제를 어떤 방향과 순서로 펼치겠다 는 것을 제시하면서 읽는 이에게 전체 글을 안
내하는 기능을 한다. 따라서 서론은 논의의 필 요성과 중요성을 제기하여 본론에서 주장하는 견해가 합당하다는 것을 드러내는 소개의 역할 을 하는 부분이다. 따라서 논점이 무엇인지, 글 의 방향이 어떠한지 등이 드러나게 함으로써 글 전체의 취지가 자연스럽게 드러나도록 하는 곳이다. 이러한 면에서 서론의 기본요소는 첫 째, 문제제기에서 불확실성, 혼동, 모순, 논쟁거 리, 지식체계에서 누락된 공백을 설명하고, 둘 째, 배경설명에서는 기술적 배경, 연구현황, 참 고문헌을 토대로 비교, 검토, 고찰하게 되며, 셋 째, 탐구사항에서는 정의, 구체성, 연구목표 정 의를 제기하는 곳이라는 점에서 이병수의 주장 은 타당성을 갖는다.

이러한 차원에서 DDC 초판(1876년)의 서문 에서 밝히고 있는 주류(main class) 배정에 대 한 M. Dewey의 의견은 매우 중요하며, 주류배 정의 원칙에 대한 이해를 구할 수 있는 본질적 인 정보원이 된다. Dewey가 그의 $\mathrm{DDC}$ 초판의 서문에서 밝히고 있는 주류설정의 원칙과 방법 은 다음과 같다.

“도서관은 우선적으로 류(class) 항목”이라 할 수 있는 9 개의 특수 도서관(special library)으 로 구분된다. 이 류에는 철학, 종교 등에 대한 9 개 숫자로 번호가 매겨진다. 9 류에 역사 도서관, 7 류에 예술 도서관, 2 류가 종교 도서관이다. 이 러한 특수 도서관이나 류는 독립적으로 다루어 지며, 각각은 대 주제의 9 개의 세부 강(division) 으로 다시 나뉘어진다(Dewey 1876, 3).

Dewey는 류 항목의 설정에 대한 대원칙을 9 개의 '특수 도서관'으로 설정하고, 이러한 특 수 도서관이나 류는 독립적으로 다루어진다고 하였다. 그렇다면 9 개의 각 류는 전후의 류와의 
관계는 전혀 고려대상이 아니었다는 이론이다. 이렇다면 주류설정의 이론을 규명하는 일은 무 의미한 일이다. 9 개의 특수 도서관으로 주류를 설정하고 있는 것은 도서관분류법이라는 실용 적인 입장에서 접근하였다고 볼 수 있다. 학문 의 상호 연관성과는 아무런 관련성이 없다. 이 러한 대원칙을 설정하여 주류를 설정하였는데 도 비합리적이라는 비판을 받는 것은 문헌분류 는 지식분류에 기반하여야 한다는 원칙론에서 시작된 것이라고 볼 수 있다.

십진분류법에서 사용한 류-강 - 목의 명칭 화와 이를 부여한 것이 분류번호라는 것과 분 류번호가 갖는 계위력의 원칙을 또한 다음과 같이 설명하고 있다. "강은 각 류에 1 에서 9 까 지 번호”가 매겨진다. 그러므로 59는 5번째 류 항목(자연과학)의 9 번째 강(동물학)이다. 최 종구분은 이러한 강이 9 개의 숫자로 동일한 방 법에 의해 번호가 매겨짐에 따라 만들어진다. 513은 5번째 류(자연과학)의 첫 번째 강(수학) 의 세 번째 목(기하학)이다. 류 - 강 - 목을 부 여하는 이러한 숫자를 '분류번호'라 부르며, 이 는 도서관에 소장된 모든 책과 팜플렛에 적용 된다. 모든 도서관에 걸쳐 모든 기하학은 513 으 로, 모든 광물학은 549 로 번호 매겨져, 주어진 주제 상에 있는 모든 책들은 그 분류표의 주제 번호를 가지게 된다(Dewey 1876, 3).

그런데 류 - 강 - 목의 설정에 있어서 학문의 계위력을 강조하고 있어 주류간의 어떤 상관성 을 찾게하는 빌미를 제공한 것이 아닌가 생각 된다. 그렇지만 계위력도 주어진 주제안에서만 의미를 갖는 것이지 류를 넘어서는 그 의미 관 계성은 없다. 다만 조기성을 갖는 일부만은 여 기에서 제외된다. 그리고 류·강 - 목을 부여하
는 것이 분류번호로 명명하였다. 이는 십진식 이라는 숫자공식에도 합당한 논리이다.

다음은 분류번호에서 사용하고 있는 0(zero) 에 대한 의미성을 설명해 주고 있다. '0'이 류 · 강 - 목의 어느 위치에 첨부되느냐에 그 의미성 을 달리한다는 설명이다. 류에 0(zero)이 주어 지면, 그것은 일반적인 '0'과 같은 개념이며, '0' 이 제일 앞에 나타나는 것은 류에 제한되지 않 는 책이 된다. 또한 ' 0 '은 크다라는 의미도 가지 고 있다. 이러한 의미에서 총류에 ' 0 '을 배정한 것이다.

총류는 모든 주제를 망라하여 취급하고 있는 문헌, 내용이 3 개 이상의 큰 주제에 걸쳐 있는 문헌, 어느 주류(큰 주제)에도 포함되지 아니 하는 주제를 가진 문헌들을 분류하기 위하여 인위적으로 마련된 분류항목이다. 총류의 개념 이 처음 등장한 것은 Harris분류표로서 그것에 는 Appendix(부록)라 하여 분류표의 마지막 부 분에 배치하였는데 세부항목으로는 Polygraphy, Cyclopaedias, Periodicals로서 문헌형태나 편 집체재를 세분수단으로 삼았다. $\mathrm{DDC}$ 에서는 총 류를 분류표의 맨 앞부분으로 옮겨 놓았는데 소련 $\mathrm{BBK}$ 분류법을 비롯한 몇몇을 제외하고는 $\mathrm{DDC}$ 이후의 대부분 분류표들은 이 순서를 따 르게 되었다. Bliss의 서지분류표 $(\mathrm{BC})$ 는 총류 를 주제들보다 앞서 설정된다는 의미에서 선행 류라 명명하였다.

이처럼 $\mathrm{DDC}$ 에서 사용되고 있는 '0'의 개념 에 대해 초판에서 분명하게 밝히고 있다. "류에 0 (zero)이 주어지면, 그것은 일반적인 ' 0 '과 같 은 개념”이다. 그러므로 510 으로 분류된 책은 류가 5 , 강이 1 이지만, 목은 없는 것이다. 일반 적으로 51로 분류되는 수학이 513으로 분류되 
는 기하학에 속해 있는 것은 아니다. 500 으로 표현되어 있다면, 그것은 일반적으로 과학에 관한 논문이지만, 영역구분은 없는 것이다. 같 은 방법으로 ' 0 '이 제일 앞에 나타나는 것은 류 에 제한되지 않는 책이 된다. 분류는 주로 형식 에 관계없이 주제나 컨텐츠에 의해 형성된다. 그러나 실제 형식에 의해 부가적으로 구분하는 것은 유용하게 쓰인다(Dewey 1876, 4).

다음의 내용은 주류설정에 있어서 이론보다 실용성이 강조될 수밖에 없는 요인을 설명하고 있다. 이론적으로 9 개의 표목으로 나뉘어진 모 든 주제 영역은 모순이 있다고 Dewey는 설명 하고 있다. "분류표상의 수 천 개의 표목의 선 정 및 배열은 공간부족으로 자세히 설명할 수 는 없다." 모든 작업에 있어 철학적 이론과 정 확성은 실제적인 유용성에 양보할 수밖에 없다. 도서에 나타나 있는 모든 지식에 만족할만한 분류가 불가능하다는 것은 처음부터 인식되었던 것이며, 시도하지도 않았다. 이론적인 조화와 정 확성은 도서관의 실제적인 요구나 대학의 특정 분야의 편리성에 희생되어 왔다. 모든 표에서처 럼, 많은 사소한 주제들은 그들이 정확히 속해 있지도 않은 일반 표목에 놓여져 왔다. 어떤 경 우 이러한 표목은 ENGLISH PHILOLOGY하 에 429 Anglo-Saxon이 다른 타입으로 인쇄되 기도 했다. 규칙은 이러한 주제가 가장 근접하 게 할당된 표목이나 그것들이 가장 유용하다고 생각되는 곳에 할당되는 것이다. 유일한 대안 은 그것들을 모두 생략하는 것이었다. 실제 표 목이 잘 배열되어 있어서 각각의 주제가 가장 근접하게 할당된 주제에 의해 잘 정렬되어 있 다 할지라도, 실제 편리성은 목록과 서가 상에
서 가장 확실히 얻을 수 있다(Dewey 1876,4 ). 이론적으로 9 개의 표목으로 나뉘어진 모든 주제 영역은 모순이 있다. 실제적으로는 부가 적인 숫자나 10 진법에 의하지 않고 가능한 상 세하게 분류하는 것이 바람직하다. 이러한 원 칙이 실제 가장 만족도가 높은 것으로 나타났다. "도서관에서는 류(類) 숫자에서 3 개의 숫자를 균일하게 사용하는 것이 가장 좋은 것으로 나타 났다. 이는 어떤 특정 주제분야를 아주 상세하 게 분류할 수 있도록 해준다. 그러나 History of England는 분류표가 개발될 때와 마찬가지로 유일한 섹션이며, 그러므로 두 개는 대등한 것 이 된다. 그러한 경우 좀 더 세밀한 분류를 하기 에 충분히 중요한 어떤 주제에 대해 9 개의 숫자 를 부여함으로써, 네 번째의 숫자를 사용하는 것에는 명백한 어려움이 있다. 전반적으로 국 가별로 주어진 분류의 역사를 보면 네 번째 숫 자는 기간을 구분하기 위해 부가된 것이다. 10 개로 구분하는 각각의 숫자를 부여함으로써 상 세함의 바람직한 정도가 특정 주제를 분류하는 데 있어 정해진다. 공동작업이 부족하게 되면, 자료의 목록작업에 있어 이러한 더 중요한 표 목에는 처음의 3 개의 번호만이 부여되고, 네 번 째 번호나 하위 강(綱)은 부여되지 않게 된다. 이러한 하부 강(綱)이 커지는 것이 정당해 지 기 위해서는, 어떤 한계 없이 확장시키기 위해 서 네 번째 번호가 부여되어야 한다(Dewey 1876, 4-5)." 이처럼 주류설정에 있어서 이론보 다 실용성이 강조될 수밖에 없는 요인을 설명 하고 있다. 


\section{5. $\mathrm{DDC}$ 주류배열의 논리성과 비논리성}

\subsection{DDC 주류배열의 논리성}

Dewey는 지식의 전 분야를 9 개의 범주로 구 분한 뒤 총류를 선행시키기 위해 0-9의 번호를 부여하였다. 이러한 10 류의 구분배열은 이론적 이라기보다는 실제적 편의성을 고려한 것이다. 이는 또한 이용자의 편의성을 우선적으로 고려 한 조치라고도 할 수 있다. 편의성이나 실용성 을 중요시 한 것은 Dewey뿐만이 아니고 C. A. Cutter도 같은 궤를 유지하였다. 그의 실용주 의적 접근은 목록법의 3 대 기본원칙 중 제 1 원 칙으로 이용자의 편의성과 습관성 우선의 원칙 으로 "이용자의 편의성은 항상 목록작성자의 용이성보다 우성되어야 한다." (Cutter 1904, 3) 고 주장한 바와 동일하다.

그러나 실용적 측면에 기반한 주류 배열순에 전혀 이론적 근거가 없는 것만은 아니다. 구분 원리에 대해 몇몇 학자들의 논리를 종합해 보 면, 비록 이것이 DDC 창안 당시 Dewey에 의 해 구축된 이론이 아니어서 임의적이거나 일부 러 Dewey의 이론에 억지로 맞추기 위해서 구 축된 것인지는 몰라도 다음과 같은 이론은 주 류순의 비논리성의 비판에 대한 순기능의 이론 을 제공해 주고 있다.

먼저 Mary P. Douglas는 『사서교사핸드북 (The Teacher-Librarian's Handbook)』에서 DDC 주제배열의 논리를 다음과 같이 전개하고 있다 (Douglas; 김태률, 1960, 58-59). 100-199 철 학(哲學); 시초에 인간은 자기 자신에 관하여 생각하고 왜 이 세상에 놓여 있는가 하고 이상
하게 여기기 시작하였다. 인간은 이 세상에 있 어서의 그들의 존재에 대하여 누가 책임을 지 고 있는가를 힘써 논구해 보았다. 경험을 통해 서 인간은 선하지 않으면 벌을 받으리라는 것 을 배웠다. 이러한 생각은 100 대에 편입된다.

200-299 종교(宗敎); 이 세상에 있어서의 그들의 존재는 신의 덕택이라고 확신했으므로 그들이 그것을 숭배하는 것은 당연한 일이었다. 그리하여 우리들은 모두 민족의 종교를 포괄하 는 200 구룹을 마련하고 있다.

300-399 사회과학(社會科學); 이 세상의 인간들은 함께 살아야 하며, 그리고 평화와 조 화를 위하여 법률이 필요하다는 것을 멀지 않 아 깨달았다. 그들은 또한 교육과 정부를 희구 하였고, 그리고 천연 및 인적자원의 보전에 노 력하였다. 300 대는 이러한 것을 모두 포괄한다. 400-499 언어(言語); 조직에 대한 필요성 은 곧 의사전달의 필요를 야기 시켰다. 그리고 의사전달은 언어에 따르게 되는 것이며, 이 언 어는 곧 400 구룹인 것이다.

500-599 순수과학(純粹科學); 이 세계에서 는 인간만이 존재하는 것이 아니다. 동물, 꽃, 바위가 있고 성좌와 별 그리고 사람의 주의를 끌며 고려해야 할 여러 가지의 다른 사물이 있 다. 이러한 사물이 500 대를 구성한다.

600-699 응용과학(應用科學); 인간에게 도 움이 되는 모든 요소는 이용할 필요가 있었다. 발 명과 기계는 건강의 증진, 경작, 가정, 제조업의 개량에 도움이 되었다. 이 응용과학은 분류 600 의 기본을 이루고 있다.

700-799 예술(藝術); 안이한 가정생활의 시 작과 여가시간의 증가로 말미암아, 인간의 예민 한 감성은 회화, 조각, 음악, 그리고 기타의 예술 
에 표현되었다. 이들은 700 대에 모아진다.

800-899 문학(文學); 문학은 의당 미술을 통한 인간의 표현에 따라서 이루어진 것이며, 그리고 인간은 각종 사물에 관하여 쓰므로서 자신의 생각을 표현하기 시작했다. 인간은 그 의 감정을 시로 을으고 이야기를 썼다. 그리하 여 800대는 그 전개를 나타내고 있다.

900-999 역사(歷史); 인간은 그들의 업적 의 덕분으로 각 나라를 방문하고, 자기 나라의 생활과 역사를 전할 수 있었다. 그들은 또한 그 들의 발달을 자랑하고 그들의 투쟁이나 발전을 자손들에게 알려 줄 것을 원했다. 인류의 이야 기는 곧 역사가 되고 900 대에서 분류한다.

000-099 총류(總類); 전술한 모든 분야에 걸 쳐서 누적된 풍유한 지식이 모든 인간에게 이용 되도록 한데 합친다는 것은 현명한 일이라고 보 았다. 백과사전 또는 총류에 대하여 000 대에 번 호가 부여된다(Douglas; 김태률, 1960, 58-59).

이처럼 $\mathrm{DDC}$ 가 9 개의 주류를 설정한 이유를 각 류별로 논리적으로 설명해 주고 있다. Douglas 는 친 $\mathrm{DDC}$ 파이며, 친 Dewey파이며 또한 $\mathrm{DDC}$ 매니아라고 할 수 있을 정도로 Duet파들이 비 논리적이라고 한 간극을 메꾸려고 노력한 흔적 이 베여있다. 이를 다시 정리하면 다음과 같다.

상기의 주류배열의 원리를 다시 요약하면 다 음과 같다. “총류(generalia)를 혼돈(Chaos)이 라고 한다면, 이 혼돈에서 추출된 최초의 것은 사람다운 특성, 즉 이성(reason), 환언하면 정 신(mind)이므로 그는 이 정신을 최초의 류, 즉 철학에 배정하였다. 사람이 추리할 수 있게 되 자 그가 생각한 것은 누가 사람을 만들었느냐 는 것이다. 이리하여 사람들은 만물 위에 덮인 신적인 위력(divine power)을 생각하고 이것
을 숭배하게 되었다. 그런고로 그는 사람의 제 2 위업(偉業)으로 종교를 삼은 것이다. 사람은 서로 모여서 가족이 되고, 부락이 되고, 후에는 국가를 형성하게 되었다. 제 3 의 위업으로 사회 학(sociology)을 연구하게 된 것이다. 타인과의 교제상 제일 필요한 것은 언어였으므로 언어학 (philology)을 두었고, 사람은 그 환경에 있어서 의 지식이 여하히 필요한 것인가를 알 수 있게 되므로 필연적으로 과학(science)이 수반되고 배워 얻은 생명을 유효히 보지(保持)하는 과정 으로서 유용기술(useful arts)이 필요하며, 이것 을 미화(美化)하는 것이 예술(fine arts)이고, 최후에 언어를 통해 여하히 기록하느냐가 문학 (literature) 및 역사(history)이다(Sayers": 加 藤宗厚 譯 1931, 590-591)”라는 논리이다.

한편 Harris는 Hegel의 사상을 이론화하고 발 전시킨 가장 중요한 대표적인 학자이다. Harris 의 세계관이 Dewey의 분류법에 기본 골격을 제공하였으므로 주류설정의 원리를 규명해 보 고자 한다. 즉, Harris의 차원에서 주류의 설정 과 배정의 원리를 고찰하면 다음과 같다.

Eugene E. Graziano는 DDC 주류배정에 대 한 어떤 원리나 철학에 대해 "일찍이 금세기에 그 문제는 분류학자들에게 큰 관심거리였다. 그 러나 어떤 만족스런 해답을 얻지 못했고 결국 그 의문은 더 이상 질문되지 않고 있다(Graziano 1959, 45-52)"고 언급하고 있다.

그런데 최근에 K. F. Leidecker의 논문에서 그 의문이 다시 시작되었다(Leidecker 1946, 399; Leidecker 1945, 139-142). Leidecker는 $\mathrm{DDC}$ 에서의 주제 주류의 배열은 역사적 순으 로 이끌어낸 것이며, 그리고, St. Louis Public School Library에서 고안된 Harris 분류법의 
배열을 따른 것이라고 주장하였다. 이제 그 의 문은 "DDC는 왜 Harris 분류법의 배열을 따랐 는가?"(Dewey 1876, 3-4)로 집중되고 있다.

19세기 후반에, 만들어진 대부분의 도서 분 류법 체계에 대해 주요하게 요구했던 것 중 하 나는 동일한 주제들은 함께 놓아두도록 하고, 한 주제에서 또 다른 주제로의 전개는 논리적 으로 전개하도록 하는 것이었다. 이러한 요구 때문에 도서 분류는 난해한 문제로 매우 복잡 하게 되었다. 무엇이 현실적 이론에 의한 논리 적 분류인가?(Graziano 1959, 45)이다.

Harris는 공인된 Hegel 철학자로 본인도 인정 하고 있다. 그는 1858년부터 1879년까지 Hegel 철학을 연구했고, Hegel 철학은 그의 모든 활 동의 기초가 되었다. 그가 언급하길 "...심지어 야생 칠면조나 다람쥐 사냥도 철학에 의해 이 루어진다." 그래서 철학은 우리에게 지식의 모 든 면에서 가장 실용적 의미를 갖게 된다. 철학 은 모든 문제를 해결하는데 사용된다....나는 1860년 이후로 내 모든 생각에 대한 일종의 센 터로서 이러한 〔헤겔의〕 논리학 주제를 갖고 매우 꾸준히 연구해왔다... (Harris 1895, v).

1870년에 St. Louis Public School Library 는 Harris가 고안한 체계를 따라 분류된 첫 목 록을 발행하였다(U.S.Bureau of Education 1876, 986). 발행에 앞서서 Harris는 그의 분류 표를 『The Journal of Speculative Philosophy』 에 발표하였다(Harris 1870). 도서 분류에 대한 이런 심의에서, 그는 모든 분류표는 어떤 철학 적 체계를 기초로 한다고 진술했다. 그러나 그 는 결코 Hegel을 언급하지 않았다. 대신에, 그 는 Bacon의 지식분류가 도서 분류를 위한 기초 로는 부적합하다고 강조했다(Harris 1870, 119).
Harris는 Bacon 지식분류가 만족스럽지는 않 지만 그것을 거꾸로 하면 최소한 세 개의 주류 구분은 더 확실한 배열을 지닐 것이라고 여겼다. 분류표에 대한 Harris의 고전 논문에서 Hegel 에 대한 언급은 없었지만, 그럼에도 불구하고 Hegel의 개념은 많은 영향력을 미치고 있음은 분명하다. Bacon이 고안한 시스템에서의 순서 를 바꾸어서 다음에 무엇이 나올 것인가에 대 한 방법과 원칙을 두는 것 때문에 과학은 첫 번 째에 놓여져야 한다. "Bacon이 고안한 그 체계 의 배열을 거꾸로 한다면 Science가 왜 우선되 는가에 대한 설명이 필요하다." Hegel과 그 이 전의 Bacon과 Johnston을 염두에 두고 Harris 는 그의 시스템을 다음과 같이 요약하고 있다.

1) 과학은 conscious system 이 보편화된 분야 에 해당된다.

2) 예술(미학)은 'organic unity' 나 unconscious system이 보편화된분야에 해당 된다.

3) 역사는 그 체계가 시간이나 공간과 같은 우연한 연관성에 의해 결정되는 분야에 해당된다(Harris 1870, 119).

Graziano는 다음과 같이 지적하고 있다. 이 러한 세 가지의 포괄적인 지식의 구분은 Hegel 의 세 가지의 논리적이고 존재론적인 수준과 같 은 지식의 수준 Begriff(관념, 개념), Wesen (본질), Sein(존재) 과 관계가 깊거나 근본적으 로 참조가 되고 있다. Begriff는 논리적인 생각 이 다른 생각과 연관되어지는 이성의 단계이고, Wesen은 생각이나 기호가 표시되어질 수 없는 대상에 대한 관계를 설명하는 영역이며, Sein 은 개인의 특수한 존재의 단계이다. 이러한 구 
별은 그의 '변증법'에 기초하고, 게다가 헤겔의 철학에 있어 독특한 것이다.

Harris는 Bacon이 형식과 내용에 기반한 구 분요소를 사용했다는 것을 유념하고, 이를 '옳 은 방법'이라고 받아들였다. Harris는 Hegel 철 학, 논리학을 연구했으며, 그것을 문자 그대로 인식했다(Harris 1895). Harris는 그의 ${ }^{\circledR}$ Book Classification』에서, 그는 상세한 분류표를 이 끌어내는데 쓰였던 그 이론을 일일이 전개해나 갔다. 그 이론은 완전히 Hegel 철학이다. '예술 (fine arts)' 류에서, Harris는 Hegel의 세목구 분을 바로 적용했다.

Graziano의 이러한 우수한 분석은 매우 논리 적이며, 일면으로는 Begriff, Wesen, Sein 그리 고 다른 한편으로는 과학, 예술, 철학의 관계는 대응되는 것이라고는 말할 수 없다. 'Logic'에서 Hegel은 존재의 모든 양식에 대하여 논리적인 설명을 하려고 시도하였다. 그는 무엇이 존재 하는 가에 대한 반성과 인간의 인지에 대한 기 록에의 논리적인 구조를 제공하려고 시도 하지 는 않았다. Hegel은 논리적인 필요성에 의거하 여 현실을 설명하는 사상의 체계를 전개시켰다. Begriff, Sein, Wesen의 개념은 Idea 즉, 논리 적인 개념을 구성하고 있는 세성분이며 Hegel 에 있어서는 이것은 오직 현실의 일부분일 뿐 이다. 그 자체 밖의 Idea 즉, 자연과 그 자체 내 의 혹은 그 자체 즉, 정신은 역시 그의 철학의 일부분이다. 이러한 것들은 Idea 즉 모든 현실 이라고 불려 질 수 있는 또 다른 세 성분을 형 성하고 있다.

Hegel은 철학이 다른 학문들로 이루어진 단 일 학문으로 볼 수 있다고 하였다. 그것이 경험 적인 학문으로 발달되어야 하겠지만 반대로 이
러한 학문들은 논리적 기술의 기초와 연역적 가 설에 대한 철학에 기반한다. 그는 더 나아가 순 수한 철학이라면 하나의 원리가 모든 개개의 원 리를 포함한다고 하였다(Hegel 1950, 22-25). 이러한 이유 때문에, '철학'은 그의 첫 번째 대분류 주제가 되었다. Harris는 학문을 계속 전개했다. Hegel에게 절대적인 것은 신에 대한 철학적인 정의이다(Hegel 1950, 156). 신에 대 한 지식이 나온(유래된) 이유는 철학에서 최상 의 문제이고, 신학은 신에 대한 지식을 다루는 체계적인 학문이다(Hegel 1950, 73). 그러므로, '신학'은, '철학' 다음에 두 번째에 위치한다.

Harris는 그의 세 번째 대분류로 세 번째로 높은 가치를 지니는 학문으로 이끌어냈다. 사 회 및 정치학(Social and Political Sciences: Jurisprudence, Politics, Political Economy, Education, Philology)이다.

이러한 관점에서 주제류가 Hegel 철학, Begriff, Harris가 말한 'the conscious system'과 일치 한다고 결론지어진다. 지식의 그 다음 아래 단 계는 'unconscious system of Organic unity' 라고 하는, Hegel의 단계인 Wesen이라는 실재 부분과 관련된다. 자연은 그러한 유기체이고, 예술작품 또한 그렇다. 둘 다 완벽한 조화속에 서 다양성을 갖고 있다. 자연은 예술 앞에 온다. 왜냐하면 모든 형식은 물질에서 얻어지기 때문 이다(Hegel 1949, 284-342). 이러한 개념에서 '변증법적 유물론(dialectical materialism: 자 연과 사회의 역사적 발전을 물질적 존재의 변 증법적 발전으로 설명하는 이론으로 유물 변증 법이라고도 한다)'이라고 부르게 된 것이다.

Leidecker는 DC 본표의 주요 주제명과 그들 의 연관순서가 Harris 분류표로부터 유래한 것 
으로 보았다. Harris 분류표와 DDC는 F. Bacon 의 지식분류법과 관련된 것으로 가정하였다. 결정적이지 않더라도 Hegel 철학은 이들 류들 의 서수적 연관성을 구성시키며, 순차상에서 논리의 요구는 Hegel 철학의 측면에서 만족할 만하다(Graziano 1959, 51-52).

주류를 전개함에 있어서 Hegel과 Harris의 관계는 Graziano에 의해서 잘 설명이 되었다. 그는 논리학에서의 The Philosophy of History, The Phenomenology of Fine Art, The Phenomenology of Mind에서 보충적인 아이디어 를 인용하였다. 다음에 나오는 문장은, Hegel적 인 생각이 밑받침되었다고 보여지는 주류에 대 한 Harris의 순서에 대하여 요약되어진 기술이 다. 일반적으로 등급에 대한 설명은 분류체계 에 대한 그의 에세이에서 Harris의 의견에 근거 에 근거를 두고 있다.

Harris의 분류법의 이론을 보면 모두 과학을 포함하는 과학이 처음에 온다. 절대자에 대한 과학이며 신에 대한 지식이며 철학의 최고 우 선적인 문제인 신학이 그 다음에 온다. 신에 대 한 충실 다음에 인간의 성취됨은 국가에서 찾 기 때문에 사회과학과 자연과학은 자연히 세 번째에 온다. 논리적으로 철학은 다음에 속하 는데 왜냐하면 언어는 사회의 한 기구이며 사 회적인 인간의 산물이기 때문이다. Graziano에 따르면 Begriff 즉, Harris의 분류법의 "의식의 체계”는 여기서 끝나는 것이다. 두 번째 부분이 Wesen 즉, '유기적인 조직'의 '무의식의 체계' 는 자연과 예술을 포함한다. 자연은 예술에 우 선하는데 왜냐하면 그것은 모두 문제에 형식을 제공하기 때문이다. 자연은 수학(수서와 공간 적인 관계), 물리학(공간에 있어서의 움직임),
화학 등등으로 나누어 진다. 자연의 역사는 양 적인 과학을 낳게되며 자연과학의 각 항목은 질적인 면으로 정의된다. 인간의 목적을 위한 것 즉, 자연을 조정하는 기술(Useful Arts)는 그 다음에 온다. Harris의 미술의 순서는 근본 적으로 Hegel과 같다. 세 번째 부분은 Sein, 단 순히 존재를 말함인데 이것은 시간과 공간에 의거한 관계성이다. Sein의 본질은 특수성(독 자성)이다. 여기에는 지리학, 생물학, Harris의 분류체계에서의 역사가 포함되어진다. Hegel의 Sein에서 Harris의 과학과 예술은 중복된다는 것이 즉시 발견되어 진다. 그러나 우리는 두개 의 시스템의 철학적인 순서에 관심을 갖는 것이 지 그 용어의 적용에 관심을 가지는 것이 아니 기 때문에 이것은 별로 중요한 것이 아니다.

결론적으로 말해서, 모든 사람은 다음과 같은 사실에 의견을 같이하고 있다. 즉, $\mathrm{DDC}$ 의 윤 곽은 Willam Tolley Harris가 St. Louis Public School Library를 위해 만든 Scheme에 근본 을 두고 있다. 그러나 Harris에게 제일 중요하 게 영향을 준 것은 무엇인가? 대부분의 분류체 계에 대한 역사가들은 Bacon을 그 원천으로 보 고 있지만 내 생각으로는 Hegel이 Harris의 분 류체계의 철학적인 지주를 제공했고 그렇게 함 으로써 Harris가 Dewey가 했다고 믿어 의심하 지 않는 바이다(Comaromi. 1976, 25-29).

\section{$5.2 \mathrm{DDC}$ 주류배열의 비논리성}

$\mathrm{DDC}$ 는 계층적 분류법이다. 이는 학문이나 주제의 관련성을 나타내기 위해서 일반적인 것 에서부터 점진적으로 구체적인 것들로 전개됨 을 의미한다(Bloomsberg \& Weber 1976, 17). 
즉 아라비아 숫자를 사용하여 모든 지식을 10 개의 류로 나누고, 이것을 다시 주요한 10 개의 강목, 이를 다시 10 개의 요목, 세목으로 계속 전 개해 나가는 계층적 분류법이다. 그러나 이것 은 하나의 원칙으로 채택된 것으로 분류표에 일반적으로 적용된다는 의미이지 반드시 모든 학문이나 주제에 완전하게 적용되는 것은 아니 다. 모든 주제가 반드시 10 개의 학문 주제로 구 분된 것이 아니기 때문이다.

이 점에 Dewey는 "주제를 십진법에 엄격히 맞추었지만 실용성을 희생하지는 않았다." 십 진법은 사환으로서 사용된 것이지 주인으로서 사용된 것이 아니다. 주제는 결합 또는 분리해 서 꼭 10 개의 표목으로 두었으나, 분류표 작성 의 필요성에서 한 것이 아니라 모든 것을 고찰 한 뒤에 이렇게 하는 것이 가장 유용하다고 생 각했기 때문이었다(Dewey 1958. 44).

Dewey는 이처럼 지식을 하나의 통일된 단 일체로 인식하고(Maltby 1978, 143) 이를 전 통적인 학문분야에 따라 1 부터 9 까지 9 개의 주 제로 구분하였다. 이 주류들은 각각 광범위한 학문분야 또는 일단의 상호 관련된 학문분야를 대상으로 부여된 것이다. 아울러 그 주제가 너 무나 일반적인 성격을 지니고 있어서 어떤 유 에도 속할 수 없는 것들을 모아 총류에 배정하 여 0 류를 설정하여 열 번째 주류를 구성하여 맨 앞에 오도록 위치시켰다. 아마도 총류를 맨 앞 에 위치시킨 이유는 0 이라는 숫자의 산수적 가 치성 때문이다.

$\mathrm{DDC}$ 가 채택한 일반적인 배열방법은 첫째로 학문에 의해 배열되고, 둘째는 주제와 각 계층 의 세분주제별로 배열되며, 셋째는 지리적 및 시대적 세분에 의해 배열되며, 넷째는 표현형
식에 의해 배열된다. 그러나 이러한 패턴은 문 학류와 총류에서는 예외이다. 문학류에 있어서 순수문학의 배열은 첫째 학문에 의해서 배열되 고, 둘째는 언어에 의해서 배열되고 셋째는 문 학양식, 넷째는 저작한 시대에 의해 배열된다.

한편 총류에서는 일반백과사전(030), 정기간 행물(050), 신문(071-079), 일반전집(080), 일 반단체의 간행물(061-068) 등을 포함하며, 어떤 자료의 범주는 첫째 형식에 의해서 배열되고, 둘째는 분류표상에 마련된 언어나 장소에 의해 배열된다. 이러한 일반적인 자료는 어느 특수한 주제를 다루는 것이 아니고 어느 특정한 학문에 속하는 것이 아니기 때문에 여기에서 주제세분 이 없다. 문학류와 총류 중에서 이상에서 열거 한 부문은 때로는 형식류라고도 한다.

$\mathrm{DDC}$ 가 이처럼 계층적 분류법이기는 하지만, 총체적인 배열은 반드시 이론적이거나 논리적 인 것은 아니라는 점에 대해서는 Dewey 자신 도 언급한 바처럼 자신은 실용주의자이며 또한 $\mathrm{DDC}$ 초판의 서문에서 밝히고 있는 바처럼 "철 학적 이론 및 정확성은 실제적 유용성에 양보 할 수밖에 없다. 문헌에 기록된 대로 모든 지식 에 만족할만한 분류법 작성의 불가능성을 우선 적으로 인지하였으면서도 시도하는 일은 무모 한 짓이다. 이론적 조화 및 정확성은 도서관의 실제적 요구 또는 대학에서의 각 학문분야의 편의성에 계속적으로 희생당하여 온 것이다. 따라서 모든 분류표에서 많은 소주제들은 정확 한 곳에 속하지 못하며 일반적인 표목하에 위 치하게 된다(Dewey 1876, 4)라고 기술하고 있 다. 이는 지식분류의 원리를 이용자 위주의 편 의성에 근간을 두고 있음을 알 수 있다.

이러한 기본 입장에서 주류의 선정은 이론적 
인 입장에서 보다 실용적인 입장에서 지식을 배열할 수밖에 없는 필연성을 강조하고 있다. 또한 실용적인 입장에서 주류를 선정할 수밖에 없었던 이유를 다음과 같이 기술하고 있다. "이 론적으로 꼭 9 개의 표목으로 모든 주제를 구분 하는 것은 불합리하다. 실제적으로는 부가적인 숫자의 사용없이 가능한 상세하게 분류하는 것 이 바람직스러우며 분류법이 적은 숫자로 손쉽 게 9 개 구분에 따라 정해지는 십진원리가 바람 직스럽다. 이러한 원리는 어느 곳에서는 독특 한 협력을 파괴 하므로서 실제상의 전체적으로 는 만족감이 증명된다. 그러므로 분류번호는 통일적으로 3 자리 숫자를 사용하는 것이 도서 관에서 최상의 것으로 보인다. 이것은 이러한 것이 어떤 주제를 매우 상세하게 분류하는데 도움이 된다(Dewey 1786, 4-5)"라고 설명하 고 있듯이 십진분류법이 근간으로 삼고 10 구분 의 원칙 그 자체도 아무런 이론적 근거가 있는 것은 아니다. G. G. Dewe도 기술한바 처럼 "자 연은 결코 지상에 존재하는 모든 것을 10 개군 으로 정돈할 수 있도록 되어 있는 것은 아니기 때문이다(Dewe 1932, 162)."

상기에서 "부가적인 숫자의 사용없이 가능 한 상세하게 분류하는 것이 바람직스럽다고 한 논리는 Charles A. Cutter도 이 점에 대해 동의 하면서 "지나치게 상세하면 구분이 과다하여 도서의 검색에 불편하므로 '상세히 상세히 하 되 지나치게 상세하지 않도록(Be minute, be minute, be not too minute)' 경계하고 있다(정 필모 1991, 143).”

분류법에 대한 Dewey의 입장은 상술한 바 처럼 근본적인 태도에서 유-강 - 목 등 그들 상호간의 이론적 연대는 창안당시부터 특히 중
요한 문제로서 인식하지 않는 것이 분명한데, 그의 분류법에 대해 가해진 가장 큰 비판의 대 상이 된 것이다. 그것은 Dewey가 분류법을 창 안할 당시의 의도와는 별도로 19세기 말부터 문헌분류법에 대해서는 하나의 주제로부터 다 른 주제로의 연속에 이론성을 강하게 요구하게 되었기 때문이다.

이러한 요구는 필연적으로 $\mathrm{DDC}$ 에 있어서 무엇 때문에 '신학' (후에는 종교로 개칭)이 '철 학' 바로 다음에 위치하고 사회과학과 역사가 그 사이에 연관성을 갖지 않는 많은 주제(어학, 자연과학, 응용과학, 예술, 문학) 들을 삽입시켜 그 양자를 멀리 분리시켜 놓고 게다가 또한 어 학과 문학이 격리된 형식을 취하고 있는가라는 의문을 갖게되어 그것들은 비논리적이라는 입 장으로부터 비판의 대상이 된 것이다. 그렇지 만 이러한 비판의 대상은 아직까지 만족할만한 해결책이 제시되지 못하고 있는 실정이다.

Graziano에 의하면 어떤 도서관이라도 이상 의 유사 주제가 멀리 떨어져 역으로 분명하게 관련이 없는 주제가 근접한 관계에 놓여져 있 는 것에 대해서 이상한 생각을 하여 왔겠지만 만 족할 수 있는 해결책은 얻지 못한 데로 결국은 그 문제를 이제는 질문하려고 하지 않게 된 것이 다. 그리하여 이러한 불문의 오랜 기간을 경과하 여 다시금 그것을 문제로 한 계기로 만든 것은 1949년 K. F. Leidecker의 William Harries에 관한 연구이고 더욱이 $\mathrm{DDC}$ 의 주류는 Harries 분류법에서 발전된 것이며, 그 순서에 따른 것 인 이상 그 다음의 질문은 '무엇 때문에 Harries 분류법에 있어서는 그와 같은 순서를 취하였는 가'라는 식으로 거슬러 올라가서 그 이유를 추 구하여 가는 새로운 단계에 도달한 경위에 대 
해 언급하고 있다(Graziano 1950, 45). 이 점에 대해서 Sayers도 언급 한 바처럼 "Dewey분류 법에 있어서는 그 주류간에 발전적 순서를 발견 하고자 한들 그것은 헛된 일이다(Sayers 1955, 130)"라고 주장하고 있다.

다른 사람들에게는 설령 주류간의 논리적 배 열이 분류법이 구비해야 할 근본적인 것이라 할지라도 Dewey 자신은 그와 같이 생각하지 않고 다만 그것은 Harries에 의한 역베이컨식 (inverted Bacon system)에 의한 근거이고 그 사이에 Dewey 자신에 의한 새로운 논리적 정 서(整序)라는 과정이 게제하고 있지 않기 때 문이다.

주류배열의 논리성에서도 언어학과 문학의 분리가 비논리적이라는 점이 강하게 암시되어 있는데, 그것은 '언어를 통해 어떻게 기록하느 냐가 문학 역사이다라는 이론이 그것이다. 이 처럼 $\mathrm{DDC}$ 는 언어학과 문학이 분리되어 언어의 예술이라고 부를 수 있는 문학과 그 문학의 기 초를 이루는 언어학의 상호 분리 배치되어 그 모순은 태생적 결함이다.

그런데 상기의 이러한 비판은 $\mathrm{DDC}$ 의 최대의 단점으로 지적되고 강하게 비판되고 있는 것은 잘못된 논리이다. 그것은 첫째, Harries의 분류 순을 그대로 답습한 것이며, 둘째는 Dewey가 각 류는 특수도서관이라고 전제하였기 때문에 류 간의 조기성이나 의미관계에서 구분되어진 분류법이 아니기 때문이다. $\mathrm{DDC}$ 에서의 논리성 과 실용성을 각기 비판하는 일은 이제는 부질 없는 '질문의 유희놀이'에 불과하며, 그가 초판 의 서론에서 언급한 바처럼 '논리성은 실용성 에 희생당할 수밖에 없다'는 논리에 도서관의 자료군을 정리한다는 측면에서는 최선의 선택
으로 수용될 수밖에 없기 때문이다(남태우 1994, 183-216).

Graziano는 "19세기 후반에 창안된 문헌분 류법에 주요하게 요구했던 것 중 하나는 같은 주제들은 함께 놓아두도록 하고, 한 주제에서 또 다른 주제로의 전개는 논리적으로 하도록 하 는 것이었다. 이러한 요구 때문에 문헌분류는 난해한 문제로 매우 복잡하게 되었다. 무엇이 현실적 이론에 의한 논리적 분류인가 (Graziano $1959,45)$ "에 대한 의문점이 제기된 것이다. DDC 어문학의 주류순에 대한 비논리적인 점은 다음 의 몇 가지 분류법의 이론을 대비시켜 봄으로 서 더욱 극명해진다.

$\mathrm{DDC}$ 에서 어문학의 분리와 인접시키지도 못한 구조적인 결함에 대해서 Cutter는 그의 분류표에 서 어문학류를 인접시키고 있는데, X Language, Y Literature를 인접시키고 있다. LCC의 경우 에는 $\mathrm{P}$ 류에 어문학을 병치시키고 있으며, J. Brown은 그의 주제분류표(Subject Classification) 에서 $\mathrm{M}$ 류에 어문학을 병치시켰으며, Bliss의 서지분류표(Bibliographic Classification)에서 $\mathrm{M}$ 류에 어문학을 병치시키고 있다. 이처럼 $\mathrm{DDC}$ 에서 어문학을 병치 또는 인접시키지 못한 단 점을 보완하기 위해서 이후 발간된 모든 분류 표에서는 한결같이 인접 또는 병치시키고 있는 것이다. 이는 $\mathrm{DDC}$ 주류의 비논리성을 극복하 기위한 조치로 볼 수 있다.

사실상 $\mathrm{DDC}$ 의 주류배열의 문제점은 첫째, 다 른 분류체계에 영향을 준 Brunet은 문학과 어학 을 구분하지 않았는데(Harris는 예외), Dewey 는 구분을 한 것이고, 둘째는 사회과학과 역사 를 3 과 9 로 구분한 점이다. 셋째는 철학으로부 터 순수과학을 1 과 5 로 구분한 것으로 이는 철 
학적이거나 이론적, 역사적 또는 실제적이지도 못한 구분이다. 일반적으로 보통과학과 철학과 는 구분할 수 없으며, 사회의 철학은 사회의 과 학과 구분할 수 없는 것이다. 이상의 문제점들 은 지식의 분류체계에도 합치되지 않으며, 문 헌분류의 관점에서도 일관성이 없는 것이다 (Bliss 1939, 203-204).

Charles. A. Cutter가 창안한 전개분류표 (Expansive classification)는 경이로울 정도로 논리성을 지녔다고 하여 긍정적인 평가를 누려 온 대표적인 분류표이다. E. C. Richardson도 이 분류표(EC)가 현대 서지적 분류표 중 가장 논리적이고 과학적이라고 단언한 바가 있으며, 그 당시에는 이러한 견해가 사실로서 수용되었 다(Richardson 1901, 206-207).

W. B. Berwick Sayers'도 이러한 찬사를 부 언하면서 덧붙여 그의 사견을 밝힌바가 있다. "다른 분류표와 관련시켜 볼 때 간단명료한 이 상적 분류표로에로 지향해왔던 모든 장점들을 지니고 있다(Sayers' 1926, 155) 고 평가하였다. Cutter 자신이 류의 배열에 대해 언급하고 있는 데 일반적으로 '주제의 진화순’으로 배열하여 4 대 분류법 중 가장 이론적인 평가를 받고 있다.

Graziano는 그의 논문에서 " $\mathrm{DC}$ 를 이해하는 데 있어서, 예를 들면, 왜 주제류 'Theology'가 'Philosophy' 다음에 바로 오는지, 왜 ‘Sociology' 가 그토록 관계없는 류로써 'History'와 분리되 는지; 그리고, 'Philosophy'가 'Literature'와 왜 분리되는지 알기 어려운 면이 있었다.” 모든 사 서들은 이전에 $\mathrm{DDC}$ 에서 유사한 주제들이 왜 그렇게 멀리 떨어져 있는지, 그리고 보기에는 관계없는 류들이 왜 그렇게 가까이 있는지 이 상히 여겨왔다. 일찍이 금세기에 그 문제는 분
류학자들에게 큰 관심이었다. 어떤 만족스런 해 답을 얻지 못했고, 결국 그 의문은 더 이상 질문 되지 않았다. 최근에 K. F. Leidecker의 논문에 서 그 의문이 다시 시작되었다(Leidecker 1946 399ff). Leidecker는 DDC에서의 주제 주류의 배열은 역사적 순으로 이끌어낸 것이며, 그리 고, St. Louis Public School Library에서 고안 된 Harries 분류법의 배열을 따른 것이라고 의심 할 여지없이 설명하였다. 이제 그 의문은 " $\mathrm{DDC}$ 는 왜 해리스분류법의 배열을 따랐는가?"가 되 었다(Graziano 1959, 45).

그렇지만 그가 만년에 역사와 사회과학, 어 학과 문학의 두 범주를 분리시켜 놓은 것은 결 코 현명하지 못한 처사였다고 회고하고 있다. 1920년 당시 69세였던 그가 어떤 분류법에서도 완전성을 요구하는 일의 불가능성을 설명하고 난 후 '어제보다 오늘'이라는 식으로 확실히 보 다 훌륭한 분류법을 만들 수 있는 일, 따라서 그의 분류법도 그것이 최선의 것이라는 생각하 는 일의 무의미함을 강조한 후 $\cdots$ 오늘날 우리 들이 만일 새롭게 다시 출발할 수 있다면 당연 히 여러 가지 변경을 가해야 할 것이라는 사실 이다. 그럼에도 불구하고 이대로의 형식을 언 제까지 계속해 갈 수는 없다고 말해 버리는 것 도 또한 할 수 없을 것이다. 예컨대 역사가 사회 과학 다음에 위치하고 어학이 문학 다음에 놓 일 수 있게 베이컨식 순위이론(Baconian order theory) 을 버리고 제 4 류와 9 류와의 위치를 바 꾸어 놓을 정도이다(Dewey 1920, 153-54)라 고 하였다.

상기의 내용은 만일 $\mathrm{DDC}$ 를 새롭게 작성하 게 된다면 무엇보다 우선적으로 어학과 역사와 의 위치를 바꾸어 충류, 철학, 종교, 사회과학, 
역사, 자연과락, 응용과학, 예술, 문학, 어학순 으로 배열되도록 주류의 변경을 가할 것이라는 점을 시사해 준 것이다. 그렇지만 이미 언급한 바처럼 Dewey는 이론은 부단히 변화해 간다는 입장에서 문헌분류법에 새로운 이론을 축적해 가는 형식에서의 변경을 가하려는 일에는 비판 적이었고, 또한 Sayers도 지적한 바처럼 그는 원래 학자가 여러 가지로 시도해 온 지식분류의 범주에 따르는 형의 분류법은 전혀 시도하지 않 았다고 해도 좋다(Sayers' 1955, 130).

따라서 이상과 같은 주제위치의 변경이 설령 바람직스럽다고 하더라도 현실적으로는 이미 그것은 곤란하고 개변에 따라 야기될 수 있는 혼란과 폐해는 피하여야 할 것이라고 다음과 같 이 조언하고 있다. "많은 국가에서 수천의 도서 관들이 현재 $\mathrm{DDC}$ 를 사용하고 있고, $\mathrm{DDC}$ 번호 는 목록, 색인 및 기타 저작의 수많은 페이지에 인쇄되어 있다(CIP시스템의 도입) $\cdots$ 사실상 번호의 변경없이 도서관에서 전체적으로 이들 주류를 변경시키는 일은 단순하지만, 반면에 주 류분만 아니라 여기에서 파생되는 수백의 저록 을 변경시키는 일은 거의 불가능하다(Dewey $1920,154)$ "라고 주장하고 있다.

이처럼 $\mathrm{DDC}$ 에서 주류배열의 비논리성이 강 하게 비판되어 Dewey 자신도 그의 만년에 이 것에 대한 반성을 회억하고 있는 것도 사실이었 지만, 그러나 당초에 그의 구상은 그러한 비판 을 감내할 수 있는 것으로서가 아니라 그것과는 전혀 별개의 것으로 작성된 것이다. 이러한 사 실은 Dewey가 1876년에 “도서관은 먼저 류 항 목이라 할 수 있는 9 개의 특수 도서관(special library)으로 구분된다. 이 류에는 철학, 종교 등에 대한 9 개 숫자로 번호가 매겨진다. 9 류에
역사 도서관, 7 류에 예술 도서관, 2 류가 종교 도 서관이다. 이러한 특수 도서관이나 류는 독립 적으로 다루어지며, 각각은 대 주제의 9 개의 세 부 강으로 다시 나뉘어 진다. 강은 각 류에 1에 서 9 까지 번호가 매겨진다. 강은 각 류에 1에서 9까지 번호가 매겨진다(Dewey 1876, 3)."

이 이론은 9 개의 각각의 류는 다른 류와는 전 혀 관련성을 갖지 않는 독립된 것으로 인식하고 있음을 알 수 있다. 즉 독립된 도서군으로 구성 된 각기의 특수도서관으로 주류를 설정하고 있 음을 알 수 있다. 이렇게 구성된 주류의 설정에 서 어떤 논리성을 발견하겠다는 것은 무의미한 짓에 불과하다. 그러나 이 점에 대해 Sayers는 Dewey가 $\mathrm{DDC}$ 를 9 개의 별개의 분류가 그 체 계를 형성하기 위해 연합하였다(Sayers 1955, 130)라는 인상을 후세의 학자들에게 주는 것으 로 되어 버렸다는 논리를 전개하고 있다. 이것 은 주류의 비논리성에서 논리성을 찾는 일은 어쩔 수 없는 상항임을 알려주고 있다.

주류의 비논리적 체계는 Harries의 분류법을 그대로 답습하고 있기 때문에 원초적인 죄업이 다. 어학과 문학 그리고 사회과학과 역사가 멀 리 떨어져 있는 것이 큰 단점으로 지적되고 있 음은 주지의 사실이다. DDC 3판의 서문에서도 “(분류법에 있어서) 실제적 활용성과 경제성 은 요체이다. 그리고 이론적 정교함을 위해 유 용성과 비용을 손상시키면서까지 분류표의 수 정을 허용하지 않을 것이다(Dewey 1885, 22)."

Harris는 본인도 인정하는 공인된 헤겔철학 자였다. 그는 1858년부터 1879년까지 헤겔 철 학을 연구했고, 헤겔 철학은 그의 모든 활동의 기초가 되었다. 그가 말하길 “... 심지어 야생 칠면조나 다람쥐 사낭도 철학에 의해 이루어진 
다. 그래서 철학은 우리에게 지식의 모든 면에 서 가장 실용적 의미를 갖게 된다. 철학은 모든 문제를 해결하는데 사용된다 $\cdots$ 나는 1860년 이후로 내 모든 생각에 대한 일종의 센터로서 이러한 〔헤겔의〕 논리학 주제를 갖고 매우 꾸 준히 연구해왔다... (Harris 1895, V).”

\section{Richardson의 주류설정에 대한 우화론}

Ernest C. Richardson(1860-1939)은 미국 의 사서이지 서지가이다. 그는 Amherst에서 M. Dewey처럼 보조사서를 1879-80년간에 경 험한 바가 있으며, 1833 년에 개교한 신학대학 인 Hartford Theological Seminary에서 1884 부터 1990년까지 사서와 서지학교수를 역임하 였으며, 또한 Princeton 대학교에서 1890년에 서 1925년까지 도서관장과 서지학교수를 역임 하였다. 그리고 1925년에 LC 자문역을 맡기도 하였다.

그는 많은 전문직에 관련된 도서와 논문의 저자인데 그 중 대표적인 것은 1901년에 발행 한 『Classification: Theoretical and Practical』, 1927에 출판한 『Special Collections in American Libraries』그리고 1934에 발행한 『Some Aspects of Cooperative Cataloging 등은 문 헌정보학분야에 영향을 끼친 대표적인 문헌들 이다.

그는 문헌분류의 원칙을 세우기 위해 최초로 인식하고 체계화 한 최초의 사람이다. 여기에 서 '최초(the first)'가 두 번이나 반복적으로 사 용된 이유는 문헌분류의 원칙을 세운 업적과 또
한 이를 인식하고 체계화 한 첫 번째 인물이라 는 이중적인 면을 강조한 것이다. 문헌분류의 원칙이 분류학에서의 중요성을 더욱 강조한 의 미이기도 하다. 분류이론과 법칙은 1901년에 발 행한 그의『분류론: 이론과 실제 Classification: Theoretical and Practical」에 기술되었다.

Hartford Theological Seminary에서 Richardson은 지금까지 사용 중에 있는 도서관 장 서의 분류표를 개발하였다. 또한 Princeton대 학 도서관을 위해 아직까지 서가배열의 기본형 식인 Richardson분류표를 개발하였으며, LCC 의 수정 형식으로 어떤 도큐먼트에서는 지금도 사용 중에 있다. 특히 1901년에 발행한 『Classification: Theoretical and Practical 은 분류 이론을 정착시킨 텍스트로 인정되고 있다. 분류 법이론의 고전으로 평가받고 있는 이 도서가 발 행되기 전에 그는 의미있는 논문 한 편을 1885 년 ALA에서 발표한 바가 있다. 아마도 이 논 문이 분류원리를 결정짓게 된 것으로 보인다. 뉴욕의 Lake George에서 1885년의 ALA 컨퍼런스가 개최되는 동안 프린스턴 대학도서 관의 사서인 Richardson은 도서관의 장서를 분 류하기 위한 최선의 방법과 관련된 다양한 의 견을 우화양식(parable form)으로 기술한 소 논문을 제출하였다. 그 제목이 "레오왕의 분류 법: 백수의 왕은 어떻게 그의 왕국을 조직했을 까? (King Leo's Classification; or, How the king of the beasts organized his kingdom)" (Richardson 1885)이다. 제목에 나타난 것처럼 동물의 왕국에서 배열의 원칙을 정하는데 어떤 방법이 최선의 방법일까를 심도 있게 논의하는 과정을 우화의 형식을 빌어 기술한 것이다.

"어느 날, 백수의 왕인 어린 Leo가 그의 왕좌 
를 인계하자마자 조류(鳥類)왕으로부터 정말 난처한 전갈을 받게 되었다. “올빼미(Owl) 박 사가 당신의 궁전을 방문하게 될 것입니다. 그 는 매우 중요한 과학적인 조사를 수행중인데 당신의 백성들 중 정보를 가지고 있거나 알만 한 자들에게 몇 가지 질문을 하기 원하고 있 습니다... 선처를 바라며 운운...”하는 것이었 다(Richardson 1885, 208)."

그래서 그는 올빼미 박사를 위해, 그리고 독 수리(Eagle) 왕을 위해, 자신의 백성들을 모두 소집시키기로 결심하였다. 이는 동시에 검토와 조직의 기회를 갖는 것이기도 하였다. 왜냐하 면 토끼 Kayward와 양 Bellin 그리고 편지에 언급되어 있는 다른 이들은 어디에 있을까를 생각해 보려는 순간 상황이 매우 좋지 않으며 소재를 아는 이라곤 자신의 신하와 그 하인들 뿐임을 알게 되었기 때문이다.

그래서 사자(使者)를 보내어 올빼미 박사의 도착 이전의 어느 소정의 날 “바로 그 날이나 그 이전에” 약속 장소로 모두 모이도록 하였다. Leo는 그의 아버지와 달리 현명한 어린 동물이 었기 때문에 사전에 조정을 해둘 수 있도록 하 기 위한 것이었다. 어디 있는지 알지도 못한 채 건초더미에서 바늘을 찾기란 어렵다는 것을 알 고 있기 때문이었다.

그가 현명하기도 했지만 조언을 무시할 정도 로 교만하지도 않았다. 그래서 그의 자문단을 소집하였다 - 자신의 아버지 때의 수상이었던 여우 Reynard(Reynard the Fox에서 나오는 여우의 이름); 고양이 Tibert; 늑대 Isigrim; 곰 Bruin; Panther와 Grimbard - 그의 아버지 가 소집하여 자문을 구하고 따르던 모든 이들 을 소집하였다. 그리고는 이들에게 이들의 오
랜 경험상 뭐가 뭔지, 어디에 있는지, 특히 올빼 미 박사가 만나기를 원하는 이들을 어떻게 찾 을 것인지에 대해 가장 좋은 방법이 무엇이라 고 생각하는지를 자문하라고 하였다.

이 때 “흥(Humph)!”이라며 당나귀가 작은 목소리로 코웃음을 쳤다. “왕이라면 그들이 어 디에 있는지 정도는 알아야지. 그건 왕의 일이 야.” 다른 이들은 아무도 주의를 기울이지 않았 다. 두더지를 제외한 다른 이들은 많이는 아니 더라도 이보다는 더 알고 있었던 것이다. 두더 지는 왕의 무지와 무능이 드러난 것에 대해 동 정어린 수치심을 느꼈다. 당나귀는 왕에 대한 두더지의 존경심을 부숴버린 것이다! 그러나 왕은 참았다. 그는 당나귀와 두더지를 가엽게 여겼다. 이들의 마음에 등불을 밝혀줄 시간이 지금은 없는 것이다. 한번 실험을 해볼까 생각 도 했지만 아무리 노력해도 그다지 희망적이지 않았다. 그리고 이제 고양 Tibert가 말하려는 참이었던 것이다.

자기 얼굴을 한 번 더 온화하게 한 다음 수염 을 가다듬으며 나이 많고 확신에 찬 이 동물은 말하였다. “왕이시여, 우선 올빼미와 다른 방문 자들이 왕궁으로 들어올 때 좋은 인상을 주어 야 한다는 생각이 듭니다. 가장 풍채가 좋은 이 를 성문 근처에 배치할 것을 건의 드립니다. 원 숭이나 나귀나 하이에나를 보는 것보다야 고양 이와 영양, 말을 보는 게 훨씬 더 좋은 인상을 받지 않겠습니까!”(Richardson 1885, 209). 그 의 동료들은 고양이의 익히 알려진 나약함에 동정어린, 아니 심술궃은 미소를 보냈다.

또 다른 이들은 원칙적으로 대칭이 될 수 있 는 키와 몸길이로 배열을 할 것을 제안하였다. “그렇죠," 고양이는 침통하게 답하였다. “좋은 
생각입니다." "그러나 키가 작은 동물의 경우 에는 어찌하죠? 당신의 원칙에 따르면 부모와 자식을 나누고 남편과 아내를 갈라놓게 될까 두렵습니다. 내 생각에는 어린 양은 야생 고양 이와 개 옆에 있기보다 양의 옆에 있는 것이 더 보기 좋습니다. 어린 코끼리는 소 옆이 아니라 점보(Jumbo) 옆이어야 좋죠."

일단 연령순대로 많은 줄 중에서 자식들은 앞줄에 세우기로 결정을 내림으로써 이 중요한 대화를 마무리한 후에 왕은 원하는 동물을 찾 아내는 실제적인 일을 어떻게 헤쳐 나갈 것인 지에 대해서는 여전히 알 수 없노라는 말을 꺼 냈다. 그가 조직하고자 하는 것은 외양이 아니 라 유용함(use)이었다(Richardson 1885, 209).

이 “유용함(use)”이라는 말은 얼음 속에 보존 되어 죽은 것으로 생각되던 마스토돈(mastodon: 신생대 3세기의 거상(巨象))에 새로운 생명을 불어넣어 주었다. "각 동물에게 번호를 매겨 리 스트를 만들지요. 그러면 당신이 원하는 것을 찾아가 구할 것입니다."

"유용(useful) 한 계획을 찾고자 하는 것은 옳다고 생각합니다”라며 비버(beaver 海狸) 가 말을 이었다. "전 실제적인 방법의 핵심은 구 분(division)이라고 확신합니다. 우선 결정해야 할 것은 구분의 수입니다. 저는 7 을 선호합니다. 7 은 완벽한 숫자이니까요. 그러나 어떤 이는 우 리 다리가 4 개라는 점에서 4 를 선호할 수도 있 습니다. 혹은 눈이 2개니 2라 할 수도 있고, 2 개 의 귀와 꼬리가 있으니 3 이라 할 수도 있겠죠. 특별한 차이가 있는 것은 아니고 단지 구분을 할 숫자를 정하는 겁니다(Richardson 1885, 209)." “... 너무 많다거나 너무 적어서 위험한 건 없을까요?”라고 왕이 물었다. “... 없습니다.”
라고 비버가 말했다. "너무 많으면 두 가지 종 류를 같이 묶어 하나로 하면 되고 너무 적으면 둘로 나누면 됩니다(Richardson 1885, 209)."

왕은 너무 예의발라 이것이 동물들을 배열할 체계를 만드는 게 아니라 체계를 설명하는 데 동물을 이용하는 듯하다는 말을 차마 하지 못 했다. 그는 이것이 각자 어느 분류 아래 놓여야 할지 알기 위해서는 리스트를 필요로 한다는 점에서 다소 매스토돈의 방법 같아 보인다고 말했다. 그러나 비슷한 동물들은 함께 둔다는 점에서 다소 진일보 했다고 생각했다.

한편 양은 수줍음을 이겨내고 단순함 $\left(\mathrm{sim}^{-}\right.$ plicity)이 진정한 유용성이라고 제안하였다. 가족은 갈라져서는 안 된다는 데 모두 동의하 는 것 같았다. "그러니까, 가장 단순한 방식은 알파벳순으로 배열하는 것입니다 ;"라고 말했 다. 그리고는 알파벳순으로 배열된 동물 리스 트를 제안하였다.

Reynard는 리스트를 살펴보다 올삐미 박사 가 설치류(觢齒類)를 원한다고 할 경우 비버에 서부터 다람쥐까지 모두 모아야 한다는 것을 알 게 되었다. 그리고 개는 개, 하운드(hound), 마 스티프(mastiff), 스패니얼(spamiel), 그레이하 운드(greyhound), 불독(bulldog), 세터(setter) 등 등 등에서 뽑아야 한다는 것도. 그는 먼저 이 들을 함께 묶는 방법은 없는지 물었다.

이 분류법이 곰 $\operatorname{Bruin}$ (동화에 나오는 곰, 곰 아저씨)에게는 좋다는 생각이 들었다. 바로 조 기성(mnemonic)이다. 그게 제일 중요한 것이 었다. 원칙은 옳지만 그렇게 단순하게 적용되어 야 한다고는 생각하지 않았다. 한 종류 이상이 단일 표제 하에 함께 모이고 이들 표제는 알파벳 순으로 배열되며 이 아래 구분들도 알파벳순으 
로 배열되는 것이다. 이 방법은 말하자면 좀 더 조기성이 있는 것이었다. 그러니까 예를 들어 하 나의 분류 아래 모든 설치류를 함께 두고 비버 (beavers), 커비스(covies), 친칠라(chinchillas), 산쥐류(dormice), 산토끼(hares) 등을 배열하 는 것이다. 이렇다면 모든 개들은 함께 또는 종 류별로 알파벳순으로 배열될 것이다. 여러분은 이런 분류 계획의 우수성을 결합하여 26 개의 대분류와 편의상 7 (혹은 4 나 3 이나 2) 개의 소 분류를 둘 수 있다.

왕은 이러한 방법은 나머지의 모두를 함께 모으는 단점이 있을 것이라고 생각하였으나, 이방인인 올빼미 박사가 D 아래에서 Hound를, $\mathrm{S}$ 아래에 Eichhőrnchen을 발견하게 된다면 매 우 놀랄 것이라고 제안하였다. 분명 응용면에 서는 보편적이지 않은 것이었다.

토론은 지루해지기 시작했다. 어떤 이는 살고 있는 지리에 따라 배열되어야 한다고 생각했다. 또 다른 이는 연령에 따라, 다른 이들은 사용하 고 있는 언어에 따라, 또 다른 이들은 태어난 출 생지에 따라 배열해야 한다고 주장 하였다.

포인터(pointer)는 논리적인 방법에 대해 이 야기 했고 하운드(hound)인 커티스(Curtise)는 다소 퉁명스럽게 말하기를 최고의 철학자와 논리 학자들은 동물은 논리적으로 분류될 수 없다는 결 정을 내렸다고 하였다. 그는 말하기를 "예를 들어 논리적인 체계로 하자면 노새(mule)를 뭐 어떻 게 할 것입니까. 말(horses)에 둘겁니까 당나귀 (asses)에 둘겁니까?(Richardson 1885, 210)."

포인터는 다시 생각에 잠기고 토론은 계속되 었다. 각자 열심히 주장하기를 각자의 방식이 최상이며 가장 많은 수의 동물군에게 적용될 수 있으며, 무식하거나 학식이 있거나 가장 좋은
방법이며, 그리고 확실히 가장 실용적이라는 것 이다. 마침내 포인터가 조심스럽게 자연스런 방 식이라고 명명할 수 있는 유사성(resemblance) 으로 배열해야 한다는 것을 제안하였다.

이건 너무 당연한 사실로 환호를 받았다. 비 버(beaver)는 체계야 어떻든 상관하지 않았다. 체계는 자신의 구분에 적응될 수 있었다. 양 (sheep)은 알파벳순의 닮은꼴을 보며 자신이 말하려던 게 바로 그거라고 하였다. 곰(bear) 은 바로 그것이 조기성(mnemonic)이 의미하 는 것이라고 말하였으며, 다른 동물들은 닮은 꼴이 장소나 나이나 출생지의 가까움을 의미하 는 것으로 보았다(Richardson 1885, 210).

이제는 이렇게 연구된 것을 확실하게 말할 수 있다면서 포인터(pointer)가 계속하기를 “우리를 비롯해 우리 주변의 왕궁의 구성원들 - 새, 파충류, 물고기 - 은 척추를 가졌다는 점 으로 인해 연체동물이나 벌레와는 구별이 됩니 다. 그리고 우리는 4심방의 심장, 따뜻한 피와 털, 턱의 구조로 인해 다른 이와 구별이 됩니다. 우리들 중에도 어떤 이는 원래 앞니가 없고 어 떤 이는 두 개의 앞니를 어떤 이는 4 개를 지니 고 있으며 여러 다양한 특징들이 있습니다. 이 렇게 우리를 이가 없는 종류로 혹은 설치류 혹 은 육식류, 식충류로 구분할 수 있습니다. 그렇 다면, 이 문제를 연구한 이들이 실제적인 닮은 꼴이나 구분 짓는 특성으로 합의한 것을 택하 면 어떻겠습니까?"(Richardson 1885, 210). 이 건 분노의 폭풍을 불러일으켰다.

“당신은 너무 이론적입니다”라며 Isigrim이 다소 거만하게 말하였다. "일반인들이 쉽게 알 아볼 수 있는 닮은꼴을 사용해야 합니다. 너무 깊이 들어가면 안됩니다. 자연스런 닮은꼴을 사 
용해야지요. 그러니까 사향노루, 사향소 사향쥐 는 분명히 함께여야 하며 큰 개미핢기와 영양이, 그리고 기린과 표범이 함께여야 합니다;”라고 모두 말하였다(Richardson 1885, 210).

그러나 왕은 여기에 뭔가가 있다고 생각하였 다. "실제적인 닮은꼴이 있다면 이게 진정한 조 기성이며, 여러분이 같은 종류를 모두 함께 둔 다면 각각을 이름이나 나이나 거주지나 출생지 혹은 언어, 크기, 모양에 따라 배열할 수 있고, 하나의 디렉토리로 순서를 매길 방법이 있을 겁니다”라고 말했다(Richardson 1885, 211). 그래서 우선 그는 이 문제를 고찰한 이들을 불 러들여 일반적으로 인식할만한 관계의 근거가 있는지를 알아보았다. 그리고 포인터가 말한 대로 모인 모든 동물들을 외양적인 닮은꼴이 아니라 실제적인 관계에 따라 배열하였고 모든 이들은 실제적이라 할 수 있는 명백한 닮은꼴 이 얼마나 많은지를 알고 놀라워했다.

그래서 올빼미가 신하를 대동하고 도착했을 때 모든 동물들은 종류별로, 종족별로, 가족별 로 정렬되었다. 가족들은 종족 내에서 지리적 으로 혹은 알파뱃순으로 배열되었고 그 중에서 도 나이별로 배열되었다. 이러한 배열은 이론 적으로 완벽하지는 않았다. 여기 노새(고집불 통, 바보)가 있었다.

이 신하는 규모 면에서 균형이 맞지 않으며 오히려 이웃의 아름다움에 의해 판단되어지는 흔한(못난) 이들의 경우에 대해서도 한마디 하 였다. 그러나 올삐미는 자신이 찾는 이들을 어 디서 찾을 것인지 즉각 알아보았다. 약간의 설 명이 신하에게 주어지자 그는 배열의 근거를 알게 되었고 이 진정한 관계의 아름다움에 매 료되면서 자신이 처음에 주목했던 부분들은 대수
롭지 않게 생각되어졌다(Richardson 1885, 210). 올빼미 박사는 자신이 발견한 편의에 기빼하며 독수리에게로 돌아왔다. 레오왕은 여전히 자신의 조직법이 유용하고 실제적임을 알고 있다.

이 우화는 영미 도서관 분류가들이 신학에서 의 전문가를 부르지 않았음을 가르치고 있다. 만약 그럴 경우에는, 그리고 만약 그들이 독일 어를 이해한다면, Zưrkler 특히 Hagenbach를 먼저 불러주기를 권한다. 그렇지 않을 경우에 는 Crooks와 Hurst로 변장한 Hagenbach를 (Richardson 1885, 211).

상기의 이야기를 요약하면 다음과 같다. "독 수리 왕을 대표한 올빼미(Owl)"가 동물왕국을 조사하기 위해 오고 있었다. 사자 레오(Leo)가 올빼미의 방문을 맞기 위하여 자신들을 배열 (arranging)하기 위한 최선의 방법이 무엇인 가를 결정하기 위하여 모든 동물들의 소집을 명령했다. 누군가가 가장 잘생긴 동물을 항구 의 출입구 가장 가까운 곳에 세우고, 그리고 크 기가 같은 모든 동물들은 멋진 모습을 본존하 기 위하여 함께 나란히 세워야 한다고 제안하 였다. 그러나 독수리 왕은 동물들을 살피는 것 은 물론 그들을 찾을 수 있기를 원했다. 그래서 그 배열은 역시 실제적인 것이 되어야 했다. 동 물들에 번호를 부여하면 그들이 필요할 때 그 들의 번호에 의해서 그들을 찾을 수 있다고 제 안하였다.

세 번째 동물은 이러한 번호에 의해 계속적 인 세 구분으로 7 과 같은 매직번호에 의해서 왕 국을 구분할 수 있음을 추천하였다. 누군가가 이 방법은 각각의 구분아래 너무 많은 종류와 너무 적은 종류의 동물들이 속한다고 반대하였 다. 이 반대에 대한 대답은 "No"였다. 왜냐하면 
"우리는 간단히 두 가지를 함께 모아 그것을 하 나로 간주하거나 또는 하나를 나누어 그것을 두 가지로 부르기 때문이다."

또 다른 동물이 "가장 단순한 방법은 알파벳 순 방법이다”라고 말하였으나, 이것 역시 반대 에 부닺혔다. "안돼, 이것은 상이한 명칭의 동일 한 것들을 분산시키게 된다"는 것이다. 낮선 동 물들과 다른 동물들이 D 아래에서 "hound(사 냥개)"를 찾는 방법인 알파벳순 조기성 방식이 추천되었다. 그때 많은 외침이 터져 나왔는데, “지역별로!”, “언어별로”, “나이별로”, “출생지 별로” 등등 그리고 동물들이 자신들이 생각하 고 있는 것을 거의 들을 수 없을 때까지 외쳤다.

마지막으로 현명한 동물이 동물들을 유사점 에 따라 논리적으로 배열되어야 한다고 제안하 였다. 그러자 어떤 동물은 이것을 할 수 없다고 소리 질러 짖고, 어떤 동물은 툴툴거렸다. “그 문제를 특별히 연구했던 자들이 실제적 유사점 과 식별마크로서 인정했던 것을 왜 취하지 않 았을까?” “너무 이론적이다”라고 몇몇이 맹렬 하게 반대했다. "아니야”, "이것은 실제적 유사 점에 기초를 둔 진짜 조기성 방식이다"라고 왕 은 말했다. 그러자 올빼미는 어울리지 않음에 도 불구하고 그것을 좋아했다. 즉, 분류법의 원 칙은 유사성과 닮은꼴을 기반으로 조기성을 가 미한 유용성을 최고로 인식하고 있다.

\section{7. 결 론}

분류시스템에서는 2 가지 개념이 근본이 된 다. 군집화와 순차화이다. 전자가 주류설정의 단계이며 후자는 각 주류 내에서의 주제간의
상관성을 갖도록 하는 단계이다. 모든 문헌분 류법에서 각각의 주류를 열거하고 있으나 이에 대한 명확한 기준이나 철학이나 이론적 근거를 규명할 수는 없다. 본 연구는 아직까지도 미완 의 과제로 남아있는 $\mathrm{DDC}$ 시스템 중 주류설정문 제를 규명하였다. 이를 요약하면 다음과 같다.

첫째, 지식분류는 철학적인 측면에 초점을 맞추지만, 문헌분류는 이용자 측면에서 편의성 을 중요시 한다. 그렇기 때문에 문헌분류법에 서 논리성을 찾는 일은 무의미하다.

둘째, 그렇지만 $19 \mathrm{C}$ 후반에 창안된 대부분의 분류표들은 동일주제는 함께 놓아두도록 하고 한 주제에서 또 다른 주제로의 전개는 논리적으 로 하는 것이었다. 여기에서 $\mathrm{DDC}$ 의 주류배열에 대한 논리성의 논란이 시작되었다고 할 수 있다. 셋째, $\mathrm{DDC}$ 에서 도서관은 우선적으로 류(類 class) 항목이라 할 수 있는 9 개의 특수 도서관 (special library)으로 구분된다. 이 류에는 철 학, 종교 등에 대한 9 개 숫자로 번호가 매겨진 다. 9 류에 역사 도서관, 7 류에 예술 도서관, 2 류 가 종교 도서관이다. 이러한 특수 도서관이나 류는 독립적으로 다루어지며, 각각은 대 주제 의 9 개의 세부 강(division)으로 다시 나뉘어진 다. 유- 강 - 목 등 그들 상호간의 이론적 연대 는 창안당시부터 특히 중요한 문제로서 인식하 지 않는 것이 분명한데, 그의 분류법에 대해 가 해진 가장 큰 비판의 대상이 된 것이다.

넷째, $\mathrm{DDC}$ 의 주류배정의 비논리성이 최대의 단점으로 지적되고 강하게 비판되고 있는 것은 잘못된 논리이다. 그것은 첫째, Harries의 분류 순을 그대로 답습한 것이며, 둘째는 Dewey가 각 류는 특수도서관이라고 전제하였기 때문에 류 간의 조기성이나 의미관계에서 구분되어진 
분류법이 아니기 때문이다. $\mathrm{DDC}$ 에서의 논리성 과 실용성을 각기 비판하는 일은 이제는 부질 없는 '질문의 유희놀이'에 불과하며, 그가 초판 의 서론에서 언급한 바처럼 '논리성은 실용성 에 희생당할 수밖에 없다'는 논리에 도서관의 자료군을 정리한다는 측면에서는 최선의 선택 으로 수용될 수밖에 없기 때문이다

다섯째, $\mathrm{DDC}$ 초판의 서문에서 밝히고 있는 바처럼 철학적 이론 및 정확성은 실제적 유용성 에 양보할 수밖에 없다. 문헌에 기록된 대로 모 든 지식에 만족할만한 분류법 작성의 불가능성 을 우선적으로 인지하였으면서도 시도하는 일은 무모한 짓이다. 이론적 조화 및 정확성은 도서관 의 실제적 요구 또는 대학에서의 각 학문분야의 편의성에 계속적으로 희생당하여 온 것이다.
여섯째, Chan은 DDC에 있어서 9개의 주류 중에 6 개의 류가 인문과학 속에 속한다는 하는 사실은 19 세기에 있어서의 학문상황을 반영하 는 것이라고 분석하였다. 이러한 주류배정은 19 세기의 학문의 전반적인 특성을 반영하였다기 보다는 Amherst College 교과과정의 편성과 이에 따른 도서관의 장서개발정책에 따른 소장 장서의 특성에서 기인한 것으로 볼 수 있다.

일곱째, 그러나 친 Dewey파인 Douglas나 Sayers'는 Dewey가 각 류간에는 아무런 연관 성을 갖지 않는다고 하였지만 그들 상호간의 논리적 관계성을 규명하였다. 또한 Richardson 은 동물들의 우화 애기를 들어 논리적 분류법 이 최상이지만 도서관에서는 유용성을 우성시 하여야 한다고 주장하였다.

\section{참 고 문 헌}

[1] 남태우. 1994. DDC초판과 2판의 비교연구. In 문헌정보학논총; 이재철교수 정년기념논문집, 구미 무역(주).

[2] 더글러스, 메리. 1959.『사서교사 핸드북크』. 김태률 옮김. 서울: 연세대학교 도서관학과. 원전 The Teacher-Librarian's Handbook. 1949.

[3] 이병수 역. 1965. 멜빌 듀이 서설. 국회도서관보 2, ('65.10). 65-75, 2,('65.8). 24-36, 2,('65.9). 38-44.

[4] Amherst College, Amherst Mass. 1876. Public Libraries in the United States of America (Chapter III, College Libraries), 75-77.

[5] Richardson, E. C. 1930. Classification; theoretical and practical. 3rd. ed. N.Y., Wilson, 157.

[6] Bibliotheca Thuana. 1679. Paries, Quesnel.

[7] Bliss, H. E. 1939. The Organization of Knowledge in Libraries and the subject-approach to books. 2nd ed. New York, The Wilson H. W. Wilson Co.

[8] Bloomsberg, M. \& Weber, Hans. 1976. An Introduction to Classification and number building in Dewey. Colorado, Libraries Unlimited.

[9] Brown J. D. 1898. Manual of library classification and shelf arrangement. London, Library 
Supply Co.(section 5).

[10] Brown, J. D. 1898. Manual of library classification and shelf arrangement. Lond., Library Supply Co.(Section 2).

[11] Chan, Lois M. 1985. Cataloging and Classification. New York, McGraw-Hill.

[12] Comaromi, J. P. 1976a. "Knowledge Organized is Knowledge Kept; The Dewey Decimal Classification, 1873-1976." The Quarterly Journal of the Congress, Vol.33, No.4 (Oct.).

[13] Comaromi, J. P. 1976b. The Eighteen Editions of the Dewey Decimal Classification. Albany, Forest Press Division.

[14] Cutter, C. A. 1904. Rules for a Dictionary Catalog, 4th ed. Washington D.C., GPO.

[15] Dewe, G. G. ed. 1932. Melvil Dewey; seer: inspirer: deer, 1851-1931. N. Y., Lake Placid Club.

[16] Dewey, M. 1876. A Classification and Subject Index for Cataloguing and Arranging the Books and Pamphlets of a Library. Amherst, Mass.

[17] Dewey, M. 1885. Decimal Classification and Relative Index for arranging cataloging and indexing public and private libraries and for pamplets, clippings, notes, scrap books, index rerums, etc. 2nd ed. Boston, Library Bureau.

[18] Dewey, M. 1920. Decimal Classification Beginning. Library Journal, vol.45, no.4.

[19] Dewey, M. 1958. Decimal Classification and Relative Index, 16th ed. by B. A. Custer. New York, Forest Press INC.

[20] Douglas, M. P. 1960. 사서교사핸드북크=The teacher-Librarian's Handbook. 김태율역, 서울: 연세대.

[21] Edwards, Edward. 1859. Memories of Libraries, 2 vols. London, Trubner.

[22] Engley, Donald B. 1947. The Emergence of the Amherst College Library, 1821-1911. Illinois, Chicago.

[23] Graziano, E. E. 1950. "Hegel's philosophy as basis for the Dewey Classification Schedules." Libri, vol.9, no.1.

[24] Harris, W. T. 1895. Hegel's Logic, A Book on the genesis of the mind, a critical Exposition. Chicago, S. C. Griggs.

[25] Harris, W. T. 1870. "Essay on Classification," Catalogue, Classified and Alphabetical, of the Books of the St. Louis Public School Library. St. Louis, Missouri Dem. Book \& Job Print.

[26] Harris, W. T. 1870. Book Classification, The Journal of Speculative Philosophy, IV (April, 1870).

[27] Harris, K. F. 1945. Debt of Melvil Dewey to William Torrey Harris, Library Quarterly, X V (April). 
[28] Hegel, G. W. F. 1900. The Philosophy of History, New York, Colonial Press.

[29] Hegel, G. W. F. 1920. The Philosophy of Fine Art, London, G. Bell Ltd. 1920), III.

[30] Hegel, G. W. F. 1949. Phenomenology of Mind, 2nd ed. New York, MacMillan.

[31] Hegel, G. F. W. 1950. The Logic of Hegel, Translator, William Wallance ed. London, Oxgord University Press.

[32] Leidecker, K. F. 1945. Debt of Melvil Dewey to William Torrey Harris, Library Quarterly, XV(April, 1945).

[33] Leidecker, K. F. 1946. Yankee Teacher, the Life of William Torrey Harris, New York, Philosophical Library.

[34] Maltby, A. 1978. Sayer's manual of classification for libraries. 5th ed. London, Andre Deutsch.

[35] Richardson, E. C. 1885. "King Leo's Classification; or, How the King of the Beasts Organized His Kingdom,” American library Association, Lake George Conference, 1885, Proceedings. In Library Journal, X(September-October, 1885), 208-211.

[36] Richardson, E. C. 1901. Classification, theoretical and practical. New York, The New York State Library School Association.

[37] Richardson E. C. 1930. Classification; theoretical and practical. 3rd. ed. N.Y., Wilson.

[38] Sayers', W. C. B. 1915. Cannons of Classification. London, Grafton.

[39] Sayers', W. C. B. 1931. 分類概論, 加藤宗厚 譯。圖書研究, IV.

[40] Sayers', W. C. B. 1955. An Introduction to library classification, 9th ed. London, Grafton.

[41] Tyler, William S. 1891. A History of Amherst College from 1821 to 1891. N. Y.

[42] U. S. Bureau of Education. 1876. Public Libraries in the United States of America. Part I. Washington(G. P. O., 1876).

\section{- 국문 참고자료의 영어 표기}

(English translation / romanization of references originally written in Korean)

[1] Tae-Woo Nam. 1994. DDC chopangwa 2panui Bigyoyeongu. In Munheonjeongbohak nonchong; Lee Jae-Chol Gyosoo Jeongnyeon ginyeom nonmunjip. Seoul: Gumi Trading Co.

[2] Douglas, M. P. 1959. The Teacher-Librarian's Handbook, 2nd ed. (Translated by Tae-Ryul Kim). Seoul: Yonsei University.(Original work published in 1949).

[3] Byung-Soo Lee. Trans. 1965. "Melvil Dewey Discourse." National Assembly Library Review, 2('65.8) : 24-36, 2('65.9) : 38-44, 2('65.10): 65-75. 